\title{
WPS3585
}

\section{Comparative Review OF MicrofinanCe Regulatory FrameWORK ISSUES IN BENIN, GHANA, AND TANZANIA}

\author{
Prepared by \\ Joselito Gallardo, Korotoumou Ouattara, Bikki Randhawa, and William F. Steel
}

\author{
Africa Region Financial Sector Group \\ Financial Sector Operations and Policy Department \\ World Bank \\ Washington, D.C.
}

World Bank Policy Research Working Paper 3585, April 2005

The Policy Research Working Paper Series disseminates the findings of work in progress to encourage the exchange of ideas about development issues. An objective of the series is to get the findings out quickly, even if the presentations are less than fully polished. The papers carry the names of the authors and should be cited accordingly. The findings, interpretations, and conclusions expressed in this paper are entirely those of the authors. They do not necessarily represent the view of the World Bank, its Executive Directors, or the countries they represent. Policy Research Working Papers are available online at http://econ.worldbank.org. 


\section{CONTENTS}

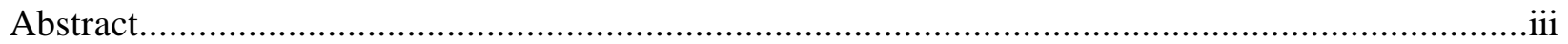

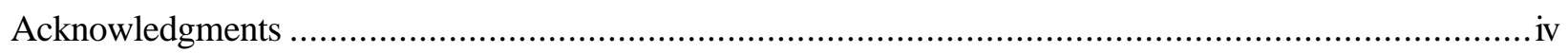

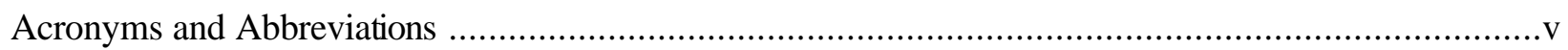

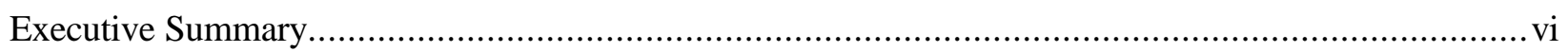

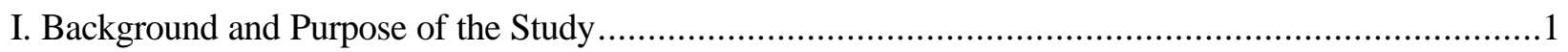

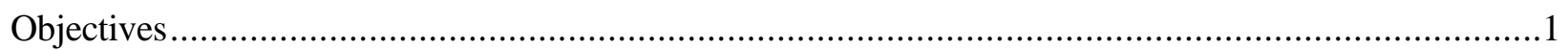

Conceptual framework: a tiered structure of microfinance institutions in a financial systems approach.....2

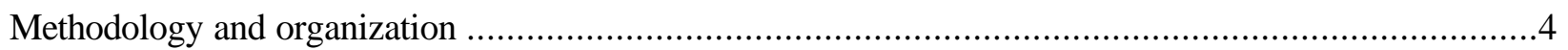

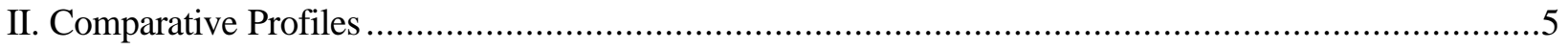

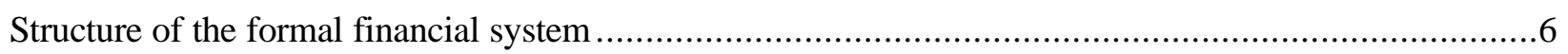

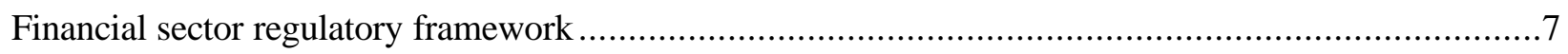

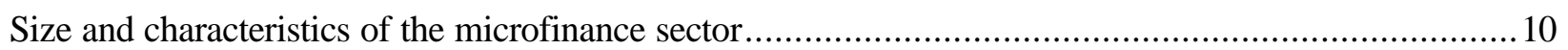

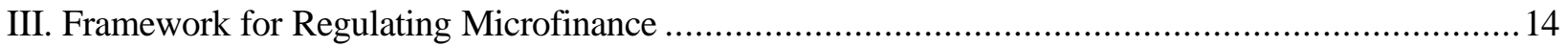

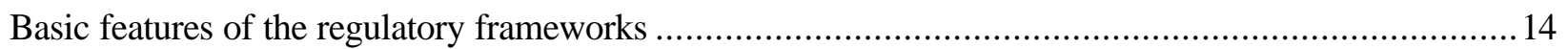

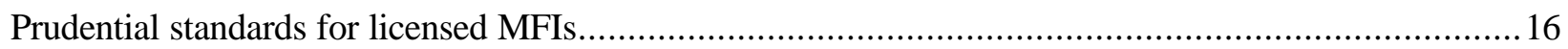

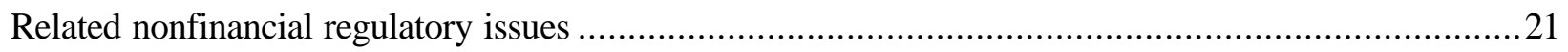

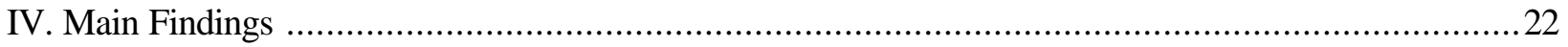

Opening the formal regulatory framework to promote growth of microfinance ................................22

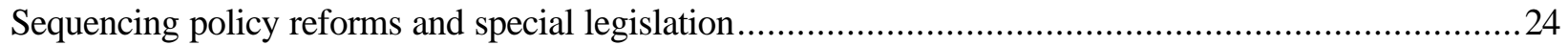

Impact of regulatory framework on microfinance development............................................25

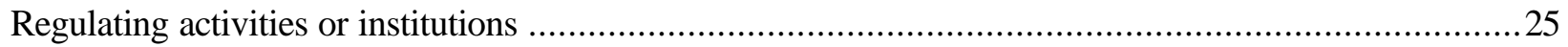

Distinguishing between prudential supervision and regulatory oversight .....................................26

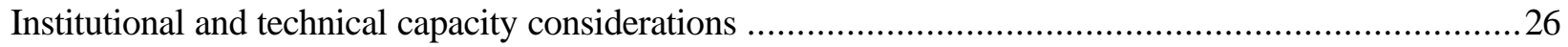

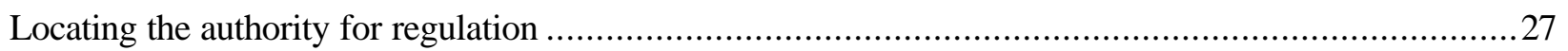

Integrating cooperative financial institutions into the microfinance sector...................................28

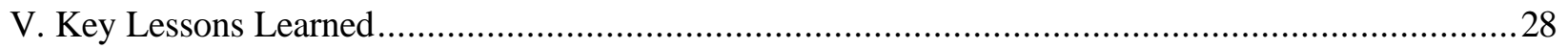

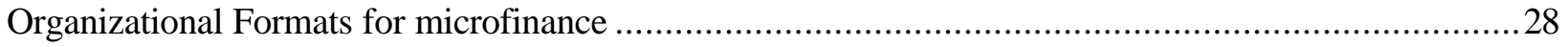

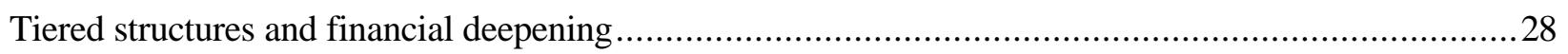

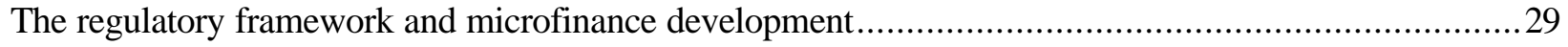

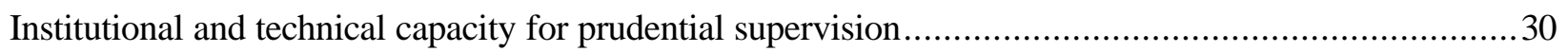

Sequencing of policy is strategic to an effective framework..........................................................

Appendix: Distinguishing Features of the Legal Framework for Different Types of MFIs.....................32

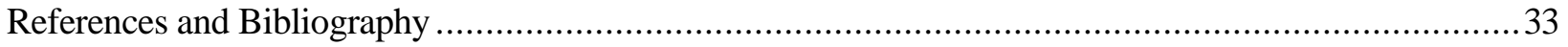


Boxes

1. Transformation to Formal, Regulated Status Enhances Access to Commercial

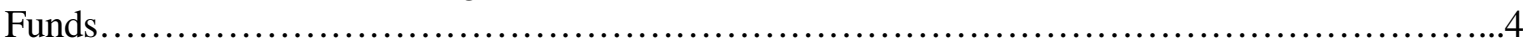

2. Facilitating Dispute Resolution through the Commercial Court, Tanzania .........................23

\section{Tables}

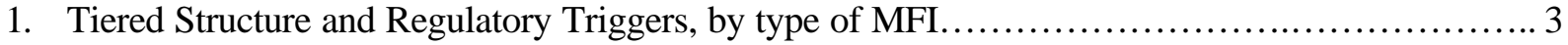

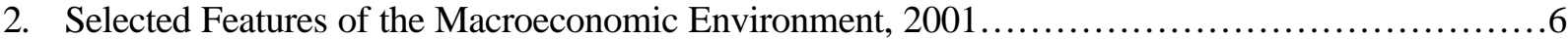

3. Comparison of Ghana's Rural Banks and Credit Unions with African MFIs, End of 2000........12

4. Thresholds of Intermediation Activities Subject to Regulation and Licensing, 2002...............15

5. Minimum Capital and Adequacy Requirements for Licensed MFIs, $2002 \ldots \ldots \ldots \ldots \ldots \ldots \ldots \ldots \ldots \ldots \ldots$

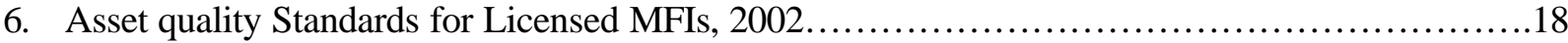

7. Risk Exposure Limits Imposed on Licensed MFIs, 2002 .................................... 19

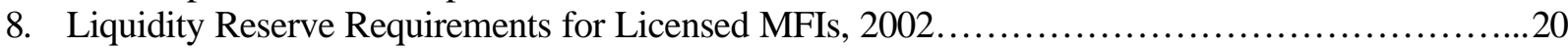

9. Formal Deposit Protection Structures, Sele cted Countries....................................21 


\begin{abstract}
Gallardo, Ouattara, Randhawa and Steel investigate the microfinance regulatory regimes in Benin, Ghana and Tanzania, with a view to identifying key issues and lessons on how the overall regulatory framework affects integration of microfinance institutions into the financial system. The authors find that recognizing different tiers of both regulated and unregulated institutions in a financial structure facilitates financial deepening and outreach to otherwise underserved groups in urban and rural areas. That environment promotes sustainable microfinance under shared performance standards, and encourages regulatory authorities to develop appropriate prudential regulations and staff capacity. Case studies of the three countries raised important issues on promoting microfinance development vis-à-vis regulating them. Laws to regulate activities other than intermediation of public deposits into loans can result in disproportionately restrictive and unmanageable standards, even as dynamic microfinance sectors have emerged without conducive regulatory regimes. The three countries' regulatory experiences are used to highlight the importance of differentiating when prudential supervision is warranted and when regulatory oversight suffices, and to identify the agencies to carry out regulation. The paper addresses an important issue that has received scant attention, measuring and paying for the costs of regulating microfinance, and the need to build technical capacity of supervisory and regulatory staff.
\end{abstract}




\section{ACKNOWLEDGMENTS}

The authors wish to acknowledge the support of the World Bank's Financial Sector Board and Africa Regional Programs in carrying out this study and the country background studies over nearly two years and the guidance received from Gerard Byam and Marilou Uy. The authors are grateful to Carlos Cuevas, Richard Rosenberg, and Andre Ryba for comments on a previous draft, as well as to workshop participants and those who contributed to or commented on the country papers and issues paper. 


\section{ACRONYMS AND ABBREVIATIONS}

\begin{tabular}{|c|c|}
\hline BCEAO & $\begin{array}{l}\text { Banque Centrale des Etats de l'Afrique de l'Ouest (Central Bank of West African } \\
\text { States) }\end{array}$ \\
\hline CAR & Capital adequacy ratio \\
\hline CFI" & cooperative financial institution \\
\hline "CUA' & Ghana Cooperative Credit Union Association \\
\hline EDPYME & $\begin{array}{l}\text { entidad de desarrollo para la pequeña y micro empresa (development finance } \\
\text { institutions for small and micro-enterprises) }\end{array}$ \\
\hline FECECAM & $\begin{array}{l}\text { Fédération des Caisses d'Epargne et de Crédit Agricole Mutuel (Benin) } \\
\text { (Federation of Savings and Credit Cooperatives) }\end{array}$ \\
\hline FENACREP & $\begin{array}{l}\text { Fédération Nationale des Caisses Rurales d'Epargne et de Crédit (National } \\
\text { Federation of Rural Savings and Credit Cooperatives) }\end{array}$ \\
\hline FIE & Fomento a Iniciativas Económicas (Bolivia) \\
\hline FINCA & Foundation for International Community Assistance (Tanzania) \\
\hline GDP & gross domestic product \\
\hline MCR & minimum capital requirements \\
\hline MFI & microfinance institution \\
\hline NBFI & non-bank financial institution \\
\hline NGO & Nongovernmental organization \\
\hline PADME & $\begin{array}{l}\text { Programme d'Appui au Développment des MicroEntreprises (Benin) } \\
\text { (Microenterprise Development Support Program) }\end{array}$ \\
\hline 'PAPME & $\begin{array}{l}\text { Programme d'Appui aux Petites et Moyennes Entreprises (Benin) (Small and } \\
\text { Medium Enterprise Support Program) }\end{array}$ \\
\hline PARMEC & $\begin{array}{l}\text { Projet d'Appui à la Réglementation sur les Mutuelles d'Epargne et de Crédit } \\
\text { (Benin) Project to Assist the Regulation of Savings and Credit Cooperatives) }\end{array}$ \\
\hline PRIDE & Promotion of Rural Initiatives and Development Enterprises (Tanzania) \\
\hline $\mathrm{RCB}$ & rural and community bank (Ghana) \\
\hline S\&L & savings and loan company (Ghana) \\
\hline SACCO & savings and credit cooperative organization \\
\hline UMOA & Union Monétaire Ouest Africaine (West African Monetary Union) \\
\hline
\end{tabular}




\section{EXECUTIVE SUMMARY}

This review identifies key issues and lessons about how the overall regulatory framework affects the ability of microfinance institutions (MFIs) to become more market-oriented and integrated with the financial system. Many countries in Africa are looking to sustainable microfinance to expand access to financial services as a linchpin of the strategy to reduce poverty. Donors are demanding better performance in terms of financial sustainability and outreach of microfinance institutions (MFIs), to better leverage their support. As MFIs grow and begin mobilizing commercial resources beyond grants, central banks are increasingly being called upon to regulate and supervise MFIs under existing or new legal and regulatory frameworks.

Recognizing that legal and regulatory structures are key to modernization, financial sector reforms in many African countries over the past decade have sought to allow banks to operate on a commercial basis, free from official intervention but within the norms of prudential supervision. Reform measures have included liberalizing interest rates, eliminating administrative credit allocation, strengthening the role of central banks in regulating and supervising financial institutions, restructuring state-owned financial institutions, and allowing entry of local and private banks into the market.

In most cases, however, progress in the formal financial system has not been accompanied by expanded access to financial services for large segments of the population. Basic deposit, payments and credit services have remained costly and beyond reach because of the poor state of roads and communications and because of complex conditions and difficult collateral requirements of commercial bank finance. Microfinance methodologies offer the potential both to make financial services available to the poor and to become commercially viable. But in the underdeveloped financial markets typical of African countries, most central banks lack both a clear understanding of microfinance methodologies and the staff to supervise them. Legislation intended to promote microfinance may impose untenable supervisory burdens, while an excessively restrictive approach may constrict innovation and expansion. This paper summarizes the findings of three country studies undertaken by the World Bank on microfinance regulation in Benin, Ghana and Tanzania to better inform its advice and project design regarding the appropriate balance among the objectives of promotion, performance, and prudential supervision.

\section{Tiered Structure of Microfinance Institutions and Corresponding Regulation}

The objective of integrating microfinance into the financial sector does not mean that all MFIs need to be regulated. The aim is to build strong regulated and unregulated institutions of all types to provide services on a sustainable basis under shared performance standards and to encourage the regulatory authorities to develop appropriate prudential regulations and staff capacity. This involves defining different tiers of financial institutions with different degrees of regulatory requirements. Lower tiers of institutions serving the lower end of the market can enable non-bank microlenders to seek greater formalization without actual licensing from a central bank.

As the industry grows, adding a licensing tier that permits MFIs to mobilize savings and other commercial sources of funds legally can encourage capacity building and innovation aimed at selfsufficiency and greater outreach. Another approach is to open a special window for microlending as a product that enables commercial banks, as well as alternative specialized institutions, to benefit from different cost and regulatory structures. Licensing of rural and community banks can also facilitate the emergence of new types of MFIs serving specific markets. On the other hand, premature creation of special tiers with easy entry may result in weak institutions and risks overwhelming inadequate supervisory resources. Hence licensing of MFIs should be designed to balance promotional and prudential objectives. 
Table 1. Tiered Structure and Regulatory Triggers, by Type of MFI

\begin{tabular}{|c|c|c|c|}
\hline Type of MFI & $\begin{array}{l}\text { Activities that trigger } \\
\text { regulation }\end{array}$ & Forms of external regulation & $\begin{array}{l}\text { Recommended } \\
\text { regulatory authority }\end{array}$ \\
\hline $\begin{array}{l}\text { Informal savings and credit groups } \\
\text { funded by member fees and savings }\end{array}$ & None & None required & None required \\
\hline \multicolumn{4}{|c|}{$\begin{array}{l}\text { Category A: Nongovernmental organizations } \\
\text { (NGOs) funded by donor funds }\end{array}$} \\
\hline $\begin{array}{l}\text { Category } \mathrm{A} 1 \text { : Funding only from } \\
\text { donor grants }\end{array}$ & $\begin{array}{l}\text { None, if total loans do not } \\
\text { exceed donated funds, grants } \\
\text { and accumulated surplus }\end{array}$ & $\begin{array}{l}\text { Registration as a nonprofit } \\
\text { society, association or trust }\end{array}$ & $\begin{array}{l}\text { A registrar of societies, } \\
\text { self-regulatory body if any }\end{array}$ \\
\hline $\begin{array}{l}\text { Category A2: Funding from donor } \\
\text { grants and from commercial } \\
\text { borrowings or securities issues }\end{array}$ & $\begin{array}{l}\text { Generating liabilities through } \\
\text { borrowings to fund microloan } \\
\text { portfolio and operations }\end{array}$ & $\begin{array}{l}\text { Registration as a corporate legal } \\
\text { entity, authorization by a } \\
\text { banking authority or securities } \\
\text { commission }\end{array}$ & $\begin{array}{l}\text { A registrar of companies, } \\
\text { banking authority, } \\
\text { securities agency }\end{array}$ \\
\hline $\begin{array}{l}\text { Category B: Financial cooperatives } \\
\text { and credit unions funded by } \\
\text { members' money and savings }\end{array}$ & $\begin{array}{l}\text { Accepting deposits from and } \\
\text { making loans to members }\end{array}$ & $\begin{array}{l}\text { Registration as a financial } \\
\text { cooperative }\end{array}$ & $\begin{array}{l}\text { A registrar of cooperatives } \\
\text { or banking authority }\end{array}$ \\
\hline $\begin{array}{l}\text { Category C: Special-licensed banks } \\
\text { and MFls funded by the public's } \\
\text { money (deposits, investor's capital, } \\
\text { commercial borrowings) }\end{array}$ & $\begin{array}{l}\text { Accepting wholesale and } \\
\text { retail public deposits for } \\
\text { intermediation into loans and } \\
\text { investments }\end{array}$ & $\begin{array}{l}\text { Registration as a corporate legal } \\
\text { entity, licensing as a finance } \\
\text { company or bank (with full } \\
\text { prudential requirements) }\end{array}$ & $\begin{array}{l}\text { A registrar of companies, } \\
\text { banking authority }\end{array}$ \\
\hline
\end{tabular}

Note: This regulatory classification of MFls was originally proposed by van Greuning, Gallardo, and Randhawa in 1999, and modified by Randhawa in 2003. Except for informal groups, MFls are classified into four categories based on the structure of their liabilities, i.e. sources of funding. Cooperatives in category B have a long but inefficient history of regulation. If their deposit-taking is small in scale and limited to their members, they should be given low regulatory priority. Category $\mathrm{C}$ should not include MFIs that require mandatory savings to secure loans as long as most customers are net borrowers most of the time. Formal banks with a microfinance department are not included above as they are subject to prudential supervision, even if it is usually not adapted to the specific features of this segment of business.

Regulation of microfinance activities and MFIs may take three main forms: (i) simple registration as a legal entity; (ii) non-prudential regulations that provide standards of business operations and oversight, such as operating and financial reports to be submitted, to protect the interests of clients or members; and (iii) full prudential supervision. Prudential supervision involves verification by regulatory authorities of compliance by institutions with mandatory standards such as minimum capital levels and adequacy, liquidity management ratios and asset quality standards, as measures for financial soundness. Prudential supervision of deposit-taking category $\mathrm{C}$ institutions is aimed at protecting public savings that are being mobilized and lent out ("intermediated"), which puts them at risk of being lost if loans are not repaid.

Member-based MFIs in category B differ from local, informal savings and credit groups in that they are registered with a national authority and may be part of a national network. They are often assumed to be self-regulating through their governance structure. However, this assumption may be untenable as institutions become larger. To improve information and governance, non-prudential regulation may be appropriate, e.g., requirements to provide audited financial statements. Small cooperative groups are beyond the reach and necessity of regulation, but a transition to external supervision may be appropriate at some stage of growth for larger savings and credit cooperatives (SACCOs) and credit unions (CUs). Defining this transition threshold in the abstract is difficult, and needs to be related to the size at which a SACCO's or CU's assets approximate those of licensed financial intermediaries or pose risks that could destabilize the financial system. Regulation of MFIs in category A2 is triggered by their use of concessionary or commercial loans or the issue of securities, which signals the need to protect investors. Prudential supervision of Category A1 MFIs that lend out of grant or donated funds is not needed to protect depositors or investors. 


\section{Country Highlights}

A good legal and regulatory framework for microfinance involves adapting basic principles to the conditions prevailing in a given country in terms of the range of institutions engaged in microfinance, the thresholds already established in the financial system, and the technical capacity of the regulatory authorities. Although they represent comparable levels of economic development, low but growing income per capita, and shallow financial sectors, Benin, Ghana and Tanzania vary in the nature of their MFIs and in their experiences with microfinance regulation. Benin's regulatory experience is informed by the objective of controlling the provision of microfinance in line with regional control over banking and financial institutions and activities. Ghana's regulatory framework has been evolving to include a diversity of non-bank financial institutions (NBFIs), some serving rural and low-income sectors, under a centralized prudential regulation umbrella. Supported by international donor agencies, Tanzania is shaping its regulatory framework to promote development of commercial microfinance as a major tool in achieving poverty alleviation and related economic growth goals.

\section{Benin}

Despite its relatively small size, Benin has a diverse array of MFIs and the largest number in the West Africa Monetary Union (UMOA), which controls banking and finance in eight member states through a unified central bank. These consist of licensed credit unions or mutuelles (the only officially-recognized licensing format), registered credit-only MFIs, several donor projects with microcredit components, and a variety of informal groups and associations. The microfinance sector has an estimated outreach of 700,000 clients, with some US\$33 million in loans outstanding and US\$ 40 million in savings deposits.

UMOA's law for microfinance was intended both to promote and to bring order into the sector. The law defined SACCOs (or mutuelles) as the only officially sanctioned format, but allowed NGOs, donor projects and informal organizations to engage in microfinance if registered with the Ministry of Finance, which was tasked with supervising the entire sector.

\section{Ghana}

Ghana's formal and semiformal MFIs reach some 1.5 million clients, members and depositors, of which less than a third have loans. They include 115 licensed rural and community banks (RCBs) with over a million depositors and 150,000 borrowers; 9 licensed savings and loan companies (S\&Ls) with more than 160,000 depositors and 10,000 borrowers; and 253 credit unions with over 120,000 members. Some 60,000 borrowing clients are served by 50 microcredit non-government organizations (NGOs), but most of these entities, as well as even smaller community-based organizations, have fewer than 1,000 clients each.

Ghana's multi tiered regulatory structure evolved through early efforts in the 1970s to extend the outreach of the formal financial system and service the cocoa sector by permitting locally-owned unit Rural Banks, and subsequently through the 1993 Non-Bank Financial Institutions Act, which was intended to diversify the financial sector. Credit unions were included in the latter, but central bank supervision proved unworkable, and a new Credit Union law was prepared that envisages dual responsibility of the central bank and the Department of Cooperatives, which registers credit unions. The Ghana Micro Finance Institutions Network (GHAMFIN) cuts across formal, semiformal, and informal institutions, and is being restructured as an umbrella body governed by representatives of their respective associations. GHAMFIN's objectives include institutional performance monitoring and benchmarking to develop industry standards for unregulated, as well as regulated institutions.

\section{Tanzania}

Tanzania's tiered financial sector is relatively new and shallow, consisting of 20 licensed banks and 11 non-bank financial institutions, and a 17.5 percent level of monetization. Licensed banks dominate the system, but bank deposits amount to only 14 percent of GDP, among the lowest in sub-Saharan Africa. Three categories of registered financial institutions provide financial services to households, micro and small enterprises: (i) licensed commercial, regional and rural banks, (ii) SACCOs, and (iii) NGO-based MFIs. In contrast to Benin and Ghana, the Tanzania Postal Savings bank and several commercial banks 
(National Microfinance Bank, CRDB Bank and Akiba Commercial Bank) are the leading providers of microfinance services, with outreach that exceeds the combined outreach of SACCOs and MFIs. The 650 active urban and rural SACCOs have an estimated membership base between 130,000 to 160,000, only a fifth of them borrowers. The 60 NGO MFIs are dominated by two large NGOs - PRIDE and FINCA which have three-quarters of the market, estimated at 100,000 client-members. The NGO-MFIs serve a predominantly urban clientele, and competition appears to be growing as lenders strive to keep their base of good-paying clients. International donor agencies comprise a significant and influential stakeholder group in Tanzanian microfinance, providing technical assistance as well as funding.

Establishment of a National Microfinance Bank to retain the rural branch network of the privatized National Bank of Commerce helped motivate Tanzania's establishment of an explicitly multi-tiered regulatory framework, both to facilitate engagement of formal financial institutions in microfinance and to ease the graduation of unregulated microfinance institutions to formal status. The regulatory requirements are still emerging, and so far there has been little entry or conversion to licensed categories such as regional and rural community banks.

\section{Main Findings}

The worldwide success that MFIs and microfinance programs have achieved in making financial services accessible to the poor and microenterprises has spawned initiatives to expand them. Regulatory responses have ranged from deliberate efforts to promote microfinance development by establishing special regulatory niches to control of heretofore unregulated MFI activities. An ntermediate approach is to integrate commercial microfinance into the formal financial sector by adjusting existing regulatory structures.

Commercial microfinance on a well-organized and nationally coordinated basis is a relatively new development in the three case study countries, and umbrella organizations for microfinance have been organized only in the last few years. Formally established and regulated microfinance providers are still relatively few, and a significant portion of microcredit services are provided by the numerous informal and semi-formal entities which are mostly not regulated and often not registered. The case studies of efforts to promote microfinance, improve performance of MFIs in terms of outreach and sustainability, and regulate them raised a number of issues pertinent to microfinance regulation, as discussed below.

\section{Should microfinance regulation be used as a tool to promote growth of the industry?}

Incorporating microfinance into the formal financial system in order to expand access to financial services offers an attractive alternative to using microcredit as an instrument for socially-motivated poverty alleviation projects in that it emphasis the financial sustainability necessary to continue serving the poor over time without subsidy dependence. However, regulatory frameworks designed for objectives other than regulating the taking of deposits from the public and intermediating them into loans often result in standards that are disproportionately restrictive and unmanageable. A major task is to differentiate the regulatory oversight needed to promote fair and transparent business practices from the prudential supervision required to ensure safety of public deposits and the security of the financial system, such that public benefits are likely to justify the costs involved. Licensing and supervision of MFIs as a promotional tool works best when it is narrowly targeted on enabling commercially-oriented MFIs to take deposits and attract investors in order to fund their growth.

\section{Impact of regulatory framework on microfinance development}

Microfinance legislation has proven least effective in developing well-regulated microfinance systems when MFIs brought under new regulatory regimes fall below the triggers indicated in Table 1 and when the regulatory burdens surpass the capacity of the supervisory authorities. This is illustrated by the case of Benin. The task of supervising over 1100 retail MFIs - even just the 220 that are registered - has greatly exceeded the capabilities of the Ministry, despite its access to technical assistance. The regional central bank is now planning to take over supervision of the 40 largest MFIs. The mandatory licensing of MFIs has in effect officially sanctioned their operations, despite the government authorities' inability to assure the public that they are well-managed and adequately capitalized. 


\section{Technical capacity to supervise and be supervised: who bears the costs?}

The benefits from regulating microfinance may be limited when commercial banking standards are applied to MFIs without adequate consideration of microfinance methodologies. For supervision to be effective, the data requirements and the indicators used must be adapted to the operations of MFIs, and they in turn must adapt their information systems to central bank reporting requirements. Given the shortterm nature of MFI loan portfolios, more rigorous standards in certain areas, such as portfolio quality and provisioning, together with more frequent monitoring, may be warranted. This raises a further issue that has received scant attention: measuring and paying for the costs of supervision. The costs of supervising MFIs are likely to be greater than those for commercial banks, especially when the more numerous and small MFIs outnumber the banks. Moreover, supervision fees are usually set as a percentage of the value of assets examined, and MFIs' asset bases are much smaller than those of banks. Donors have generally supported central banks in developing regulatory guidelines and standards for MFIs, as in Ghana and Tanzania. However, more resources will be needed to address deficiencies in technical capacity - not only for the supervisory agencies, but also for the MFIs subject to regulation.

\section{Locus of regulatory policy: who should regulate?}

An important issue is the extent to which regulatory authority should be centralized, delegated, or decentralized. Like many other countries in Africa, the microfinance regulatory frameworks of Benin, Ghana and Tanzania have come into being under circumstances of fragmented authority. A central bank authority is responsible for prudential supervision of licensed banks and financial institutions, a cooperatives authority is responsible for member-based SACCOs (usually focused on registration and cooperative principles rather than financial performance), and NGO MFIs are registered with nonfinancial government agencies. Delegation of supervisory functions by the regional central bank of UMOA to Ministries of Finance has proven ineffective. In deciding how best to implement regulatory responsibilities, two distinctions are important: regulatory policy should have a single locus, while application of regulatory functions can be delegated to different regulatory units with specialized responsibilities; and the criteria and authorities for prudential supervision should differ from those for non-prudential regulatory oversight, along the lines indicated in Table 1.

\section{Cooperative financial institutions}

Financial cooperatives offer important potential for decentralizing financial services, particularly in rural areas that banks and commercial MFIs may find too costly to reach. But it has proven difficult both to promote their growth as sustainable financial intermediaries and to integrate them into formal financial regulatory systems. While Benin's microfinance law prioritizes financial cooperatives, the supervisory burden has proven overwhelming, aggravated by responsibilities for also supervising non-deposit-taking MFIs. Financial policy-makers in Ghana and Tanzania have begun to recognize the need to incorporate financial cooperatives into the regulatory framework, although they are effectively excluded in the practical application of financial regulations. Ghana's proposed approach of recognizing dual responsibilities of central bank and cooperatives authorities for CUs, with some delegation of front-line supervision to the apex body, appears promising and bears watching.

\section{Key Lessons Learned}

The experience in the three countries does not support the proposition that establishing new regulatory categories will necessarily promote commercialization of microfinance or the creation of financially sustainable MFIs where few or none exist. Experiences in other countries such as Uganda and Kenya show that a variety of viable and sustainable MFIs can emerge and develop without a microfinance-specific regulatory framework, while microfinance continues to flourish in Benin despite a restrictive legal and regulatory framework. When there is a critical mass of viable microfinance providers, new legislation to amend the regulatory framework is likely to be more productive in facilitating the transformation of high-performing non-bank MFIs to licensed status in a specially adapted niche - which is the approach that Uganda and Kenya are now taking. 
The capacities of authorities to implement their regulatory obligations and of MFIs to comply are a critical constraint on the effectiveness of new legislation in promoting and regulating microfinance. Setting up new licensing categories for rural banks and savings and loan companies in Ghana did stimulate entry of new types of MFIs that helped broaden and deepen access to financial services. Nevertheless, neither the institutions nor the regulatory authorities had adequate technical capacity to ensure compliance with regulatory standards, leading subsequently to more demanding requirements as a barrier to new entry. New legislation in Benin and Tanzania brought existing non-bank MFIs under licensing and supervisory requirements, but the goal of forcing improvements in their financial performance is not likely to be realized, because the coverage of institutions greatly exceeds the capabilities of the designated supervisory authorities and the non-bank MFIs targeted for regulation are organizationally and financially weak.

The development of a new regulatory framework for microfinance should be accompanied by complementary modifications of other business laws and regulations. This is true especially in the areas of taxation, contract enforcement, collateral registration and enforcement, securities regulations and consumer protection. These laws and administrative rules also need to be adapted to microfinance methodologies, where loan transactions and the legal status of borrowers differ markedly from those in conventional commercial banking and finance.

The creation of microfinance legal and regulatory structures should be accompanied by substantial up-front investment in raising the awareness of policymakers, consulting with stakeholders, improving systems and staff capabilities in MFIs to be regulated, and staffing up and training the supervisory authorities. As the microfinance sector develops in response to demand from underserved segments, the overall regulatory framework for the financial sector is likely to be subjected to pressures for adjustments and changes, as is the case in all three countries studied. Hasty passage of new laws or introduction of government programs without adequate consultation or awareness of good (and bad) practices risks putting in place systems with a short-term focus that may undermine longer-term development objectives. Opening up formal licensing to MFIs too rapidly may overwhelm the capacity of the supervisory authorities.

An unbalanced approach results in inadequate attention to supervisory capacity and costs in the design of the regulatory framework. The experience of MFIs in other countries demonstrates that mobilizing savings and managing them safely and profitably entails a more complex set of skills, systems and resources than accessing and intermediating wholesale commercial funds. Using the regulatory framework to push microfinance development is likely to result in overlooking other less costly and less technically demanding approaches to commercializing microfinance, e.g., regulations that enable MFIs to access commercial funds from licensed banks and forge strategic alliances with the formal financial sector.

Regulators and supervisors should distinguish between deposit-taking MFIs, whose financial soundness they verify through prudential supervision, and those MFIs that may be registered and subjected to non-prudential regulations but do not pose financial system risks for which the financial authorities bear responsibility. Credit-only MFIs that do not mobilize public deposits should be excluded from prudential supervision, to conserve scarce supervisory resources and because the public's savings are not at stake. In such cases donors, banks, and other funders can be expected to exercise adequate oversight. Small member-based savings and credit associations are normally excluded from direct prudential supervision by the regulatory authorities, although regulatory oversight by an independent body or industry association is desirable for data-gathering and performance-reporting in meeting established standards. 


\section{BACKGROUND AND PURPOSE OF THE S TUDY}

1. During the last 15 years microfinance has emerged as an important tool for poverty alleviation. The term "microfinance" refers to methodologies used to make extremely small financial transactions at reasonable levels of cost and affordability. Experience has demonstrated the potential of microfinance for expanding and deepening the access of the poor and low-income households and of their micro-enterprises to financial services. In most developing countries licensed banks typically serve no more than 5 to 20 percent of the population. The emergence of sustainable microfinance institutions (MFIs) has enhanced the development of the financial sector in many countries that have undertaken macroeconomic and financial reforms by extending the reach of the financial system to new market niches and contributing to financial deepening. However, MFIs need to change and develop as the scope of their operations grows beyond the provision of credit to include savings, insurance and other financial services, and as the scale of their operations expands to reach larger numbers of clients.

2. Global experience shows that the widely accepted objectives of financial self-sufficiency of MFIs along with significant and growing outreach is best achieved through a financial systems approach. In contrast to programs oriented toward income transfers to targeted beneficiaries, the financial systems approach emphasizes microfinance on a commercial basis as an integral part of financial sector development, whereby a wider range of institutional providers is enabled to provide a greater variety of financial instruments and services to more diverse clients, especially those at lower income levels and in rural areas. Widening client outreach and expanding product offerings requires funding resources beyond the finite limits of grants and donor funds, including borrowing from formal financial institutions, raising equity from institutional and individual investors, and accepting deposits from the public.

3. A country's legal and regulatory framework can have an important impact on licensed financial intermediaries moving down-market and on nonlicensed MFIs that want to access commercial sources of funds or to transform into licensed, specialized institutions. With the rapid growth of MFIs in African countries in the last 10 to 15 years, and with microfinance increasingly advocated by policy advisers as an instrument for poverty reduction, governments and central banks have been introducing laws and regulations to govern microfinance, whether as part of an effort to promote development of the sector, to protect the public, to achieve social objectives, or to impose greater control.

\section{OBJECTIVES}

4. The literature that documents the global experience in microfinance development identifies the legal and regulatory framework as one factor that influences the emergence of different types of institutional providers of varying kinds of microfinance services and their evolution into commercially-oriented, sustainable MFIs. Approaches to microfinance regulation both in African countries and worldwide have varied widely, from early introduction of restrictive legislation to gradual adaptation of regulation to the emerging variety of MFIs. The microfinance sector itself has evolved along a variety of patterns and growth paths in different countries and regions. This review is intended to draw lessons based on varying experiences as to the advantages and disadvantages of different strategies for regulating microfinance to provide guidance on how the regulatory framework can best promote the expansion of microfinance as part of the financial system's development and outreach.

5. The study focuses on microfinance experience in three African countries-Benin, Ghana, and Tanzaniato investigate a number of key issues pertaining to microfinance regulation, including restrictiveness, integration, policy sequencing, capacity building, and approaches to and costs of regulation and supervision. The study aims to present a comparative assessment of the influence of the legal and regulatory framework on the microfinance sector and the benefits and risks of different approaches, principally in the three countries, but also in other countries.

6. The study identifies notable achievements as well as remaining challenges the three countries face in integrating the microfinance sector into the formal financial sector. The study uses the practical lessons drawn from their experiences with the relationship between microfinance development and different policy 
and legal environments as a basis for guidance to policymakers, regulators, and donor agencies on how the structure of legal and regulatory systems may affect, and in turn be influenced by, the evolution of microfinance in different country contexts. The findings and recommendations are also intended to provide technical guidance so that the World Bank's advice and lending operations in the Africa Region can become more consistent, especially as issues of licensing and regulating microfinance institutions and activities are an increasing concern of the Bank's client countries.

\section{CONCEPTUAL FRAMEWORK: A TIERED STRUCTURE OF MICROFINANCE INSTITUTIOINS IN FINANCIAL SYSTEMS APPROACH}

7. Global experience underscores the importance of MFIs gaining access to funds from commercial sources to expand outreach to clients. This is generally possible only when the policy and regulatory environment permits such access and when MFIs have the requisite legal status and financial standing. A financial institution's ability to leverage capital funds to support a greater number of microloans is directly related to its ability to access funds from commercial sources. Funds from commercial sources consist of voluntary retail deposits, wholesale and institutional deposits, and borrowings from commercial sources such as banks and other formal financial institutions, all mobilized at market rates of interest. MFIs organized as NGOs generally have the least ability to leverage capital and the lowest percentage of external commercial funds relative to average total loans, because the legal format does not allow NGOs to mobilize voluntary deposits and restricts their ability to access commercial funds in the form of wholesale and institutional deposits or borrowings from commercial banks.

8. The objective of integrating microfinance into the financial sector does not mean that all MFIs need to be regulated. The aim is to build strong regulated and unregulated institutions of all types to provide services on a sustainable basis under shared performance standards and to encourage the regulatory authorities to develop appropriate prudential regulations and staff capacity. This involves defining different tiers of financial institutions with different degrees of regulatory requirements, as illustrated in table 1 below. Lower tiers of institutions serving the lower end of the market can enable non-bank microlenders to seek greater formalization without actual licensing from a central bank.

9. As the industry grows, adding a licensing tier that permits MFIs to mobilize savings and other commercial sources of funds legally can encourage capacity building and innovation aimed at self-sufficiency and greater outreach. Another approach is to open a special window for microlending as a product that enables commercial banks, as well as alternative specialized institutions, to benefit from different cost and regulatory structures. Licensing of rural and community banks can also facilitate the emergence of new types of MFIs serving specific markets. On the other hand, premature creation of special tiers with easy entry may result in weak institutions and risks overwhelming inadequate supervisory resources. Hence licensing of MFIs should be designed to balance promotional and prudential objectives. 
Table 1. Tiered Structure and Regulatory Triggers, by Type of MFI

\begin{tabular}{|c|c|c|c|}
\hline Type of MFI & $\begin{array}{l}\text { Activities that trigger } \\
\text { regulation }\end{array}$ & Forms of external regulation & $\begin{array}{c}\text { Recommended regulatory } \\
\text { authority }\end{array}$ \\
\hline $\begin{array}{l}\text { Informal savings and credit groups } \\
\text { funded by member fees and savings }\end{array}$ & None & None required & None required \\
\hline \multicolumn{4}{|c|}{$\begin{array}{l}\text { Category A: Nongovernmental organizations (NGOs) funded by } \\
\text { donor funds }\end{array}$} \\
\hline $\begin{array}{l}\text { Category A1: Funding only from } \\
\text { donor grants }\end{array}$ & $\begin{array}{l}\text { None, if total loans do not } \\
\text { exceed donated funds, } \\
\text { grants and accumulated } \\
\text { surplus }\end{array}$ & $\begin{array}{l}\text { Registration as a nonprofit society, } \\
\text { association or trust }\end{array}$ & $\begin{array}{l}\text { A registrar of societies, } \\
\text { self-regulatory body if any }\end{array}$ \\
\hline $\begin{array}{l}\text { Category A2: Funding from donor } \\
\text { grants and from commercial } \\
\text { borrowings or securities issues }\end{array}$ & $\begin{array}{l}\text { Generating liabilities } \\
\text { through borrowings to fund } \\
\text { microloan portfolio and } \\
\text { operations }\end{array}$ & $\begin{array}{l}\text { Registration as a corporate legal } \\
\text { entity, authorization by a banking } \\
\text { authority or securities commission }\end{array}$ & $\begin{array}{l}\text { A registrar of companies, } \\
\text { banking authority, } \\
\text { securities agency }\end{array}$ \\
\hline $\begin{array}{l}\text { Category B: Financial cooperatives } \\
\text { and credit unions funded by } \\
\text { members' money and savings }\end{array}$ & $\begin{array}{l}\text { Accepting deposits from } \\
\text { and making loans to } \\
\text { members }\end{array}$ & $\begin{array}{l}\text { Registration as a financial } \\
\text { cooperative }\end{array}$ & $\begin{array}{l}\text { A registrar of cooperatives } \\
\text { or banking authority }\end{array}$ \\
\hline $\begin{array}{l}\text { Category C: Special-licensed banks } \\
\text { and MFls funded by the public's } \\
\text { money (deposits, investor's capital, } \\
\text { commercial borrowings) }\end{array}$ & $\begin{array}{l}\text { Accepting wholesale and } \\
\text { retail public deposits for } \\
\text { intermediation into loans } \\
\text { and investments }\end{array}$ & $\begin{array}{l}\text { Registration as a corporate legal } \\
\text { entity, licensing as a finance } \\
\text { company or bank (with full prudential } \\
\text { requirements) }\end{array}$ & $\begin{array}{l}\text { A registrar of companies, } \\
\text { banking authority }\end{array}$ \\
\hline
\end{tabular}

Note: This regulatory classification of MFls was originally proposed by van Greuning, Gallardo, and Randhawa in 1999, and modified by Randhawa in 2003. Except for informal groups, MFIs are classified into four categories based on the structure of their liabilities, i.e. sources of funding. Cooperatives in category B have a long but inefficient history of regulation. If their deposit-taking is small in scale and limited to their members, they should be given low regulatory priority. Category $\mathrm{C}$ should not include MFls that require mandatory savings to secure loans as long as most customers are net borrowers most of the time. Formal banks with a microfinance department are not included above as they are subject to prudential supervision, even if it is usually not adapted to the specific features of this segment of business.

10. Regulation of microfinance activities and MFIs may take three main forms: (i) simple registration as a legal entity; (ii) non-prudential regulations that provide standards of business operations and oversight, such as operating and financial reports to be submitted, to protect the interests of clients or members; and (iii) full prudential supervision. Prudential supervision involves verification by regulatory authorities of compliance by institutions with mandatory standards such as minimum capital levels and adequacy, liquidity management ratios and asset quality standards, as measures for financial soundness. Prudential supervision of deposit-taking category $\mathrm{C}$ institutions is aimed at protecting public savings that are being mobilized and lent out (i.e., intermediated), which puts them at risk of being lost if loans are not repaid.

11. Member-based MFIs in category B differ from local, informal savings and credit groups in that they are registered with a national authority and may be part of a national network. They are often assumed to be self-regulating through their governance structure. However, this assumption may be untenable as institutions become larger. To improve information and governance, non-prudential regulation may be appropriate, e.g., requirements to provide audited financial statements. Small cooperative groups are beyond the reach and necessity of regulation, but a transition to external supervision may be appropriate at some stage of growth for larger SACCOs and credit unions (CUs). Defining this transition threshold in the abstract is difficult, and needs to be related to the size at which a SACCO's or CU's assets approximate those of licensed financial intermediaries or pose risks that could destabilize the financial system. Regulation of MFIs in category A2 is triggered by their use of concessionary or commercial loans or the issue of securities, which signals the need to protect investors. Prudential supervision of Category A1 MFIs that lend out of grant or donated funds is not needed to protect depositors or investors.

12. Tiered structures of banks and NBFIs, including MFIs, enhance the operating and market linkages among regulated and unregulated intermediaries in the continuum of microfinance institutions. Different legal structures for microfinance that regulate different tiers include community-based groups, credit-only NGO MFIs, cooperative financial institutions (CFIs), regulated specialized MFIs, NBFIs, and commercial banks with microfinance products. Policies and regulations that recognize the important roles of these different structures can strengthen the process of commercializing and scaling up MFIs that provide low-income 
households and micro-enterprises with access to a wide array of sustainable financial services. CFIs whether informal or registered (in different countries), such as SACCOs, credit unions, mutuels, or village banks - are of particular interest, both because they offer the potential for offering sustainable, community-based financial services to lower-income rural populations, and because their traditional treatment as cooperatives in most African countries poses special problems for inculcating commercial financial principles and bringing them under financial regulation.

13. The experience of microfinance practitioners in many different settings worldwide underscores the proposition that the future for sustainable microfinance lies in a regulated, licensed environment. In most countries no other environment can enable large-scale, sustainable delivery of an increasing variety of financial services to effectively link the poor to the more developed sectors of the economy (Christen and Rosenberg 2000). When MFIs' traditional (donor) sources of funds cannot keep pace with expansion in their lending business, MFIs need access to external finance. In addition to loans from upper-tier financial institutions and private institutional savings, securities issues (commercial paper) on the formal capital market may be feasible in financial sectors such as Bolivia's or Peru's, where microfinance institutions are recognized as legal entities and are an integral part of the financial system (box 1).

Box 1. Transformation to Formal, Regulated Status Enhances Access to Commercial Funds

One of the better known examples of NGO transformation is Bolivia's Fomento a Iniciativas Económicas S.A. (FIE), a for-profit MFI offering individual loans to micro-enterprises in urban areas. It began lending in 1988 as an NGO and grew its portfolio from US\$4 million to US\$12 million in only three years, with a debtequity ratio of $2: 1$. In early 1998 FIE secured its license to operate as a private finance fund regulated by the Superintendency of Banks. By year's end the organization had been able to raise its debt-equity ratio to more than 6:1, mobilizing additional funding resources from institutional time deposits and increased credit lines from commercial banks. As a regulated, formal financial intermediary, FIE was able to attract institutional deposits and banks were more willing to increase their lending limits. With its newly acquired status as a financial intermediary regulated by the banking authority, it was able to become a private financial fund that played by universally understood rules enforced by a fairly tough banking superintendency. Bank creditors of FIE knew that the accounting rules it used to produce financial statements were the same as those that they themselves used, and that the same banking superintendency that exercised prudential oversight on them also closely monitored its liquidity reserve requirements, currency risk, portfolio quality, loan provisioning levels, and other potential problem areas.

Source: von Stauffenberg (2001).

\section{METHODOLOGY AND ORGANIZATION}

14. This study is underpinned by country case studies of the legal and regulatory framework for microfinance carried out in 2002 for Benin, Ghana, and Tanzania by separate teams under a joint project of the Africa Region and the Financial Sector Operations and Policy Department (Gallardo and Randhawa 2003; Ouattara 2003; Steel and Andah 2003). ${ }^{1}$ In preparing this review, the authors supplemented the findings from the country-specific case studies with information from other reports and studies on the regulatory framework for the financial sector and for microfinance in selected other countries.

15. Even though they are geographically and culturally diverse, Benin, Ghana, and Tanzania share characteristics that are typical of African countries where microfinance could be an important tool for poverty reduction: levels of economic development are low, though per capita income is growing; rural sectors are large; financial sectors are shallow; and poverty is widespread (as participants in the Highly

\footnotetext{
A team also undertook a case study of South Africa (not published), whose unique circumstances yield only limited lessons for this review. Participants at a December 2002 workshop reviewed and discussed the findings of the three country case studies featured in this study, together with an issues paper, as a basis for this comparative study. The case studies provide more details on the macroeconomic and policy context, the regulatory framework, the financial sector structure, and the key institutional players in the microfinance sectors of the three countries.
} 
Indebted Poor Countries program, all three countries prepare a poverty reduction strategy paper). While microfinance has been important in the three countries, they differ both in their approaches to legal and regulatory issues and in the nature of the institutions providing the services, including significant variations in the treatment and level of development of CFIs. This diversity was expected to make the study richer and its conclus ions more robust.

16. The country studies were also intended to enhance World Bank advice to countries where it is actively involved in the development of the microfinance sector:

- In Benin, the Rural Savings and Loan Rehabilitation Projects I and II of 1990 and 1993, respectively, supported the establishment of MFIs and assisted the development of the Fédération des Caisses d'Épargne et de Crédit Agricole Mutuel (Federation of Savings and Credit Cooperatives or FECECAM), the apex organization of credit unions. In addition, since November 1999 the Private Sector Development Project has supported the creation of two financial institutions, the Programme d'Appui au Développement des MicroEntreprises (Microenterprise Development Support Program or PADME) for credit to microenterprises, and the Programme d'Appui aux Petites et Moyennes Entreprises (Small and Medium Enterprise Support Program or PAPME), for credit to small and medium enterprises.

- In Ghana, the Bank's Rural Finance Project in 1990-94 addressed the need for recapitalization and capacity building of rural banks, enabling the Bank of Ghana to classify at least half of them as having satisfactory status by 1996. Currently the Bank is taking the lead and working with the International Fund for Agricultural Development, the African Development Bank, and Gesellschaft für Technische Zusammenarbeit (GTZ) to implement the Rural Financial Services Project. In addition to capacity building for rural and community banks (RCBs) and other MFIs, the project provides financial and technical assistance for establishing and operating a second-tier apex bank serving RCBs, which will eventually be delegated specific supervision functions as an auxiliary of the Bank of Ghana.

- For Tanzania, the Bank has prepared a Learning and Innovation Loan specifically to establish an appropriate policy and regulatory framework for microfinance. The loan is being implemented in conjunction with a financial sector restructuring and development loan. The Bank has, in the context of this larger financial sector loan, helped the government develop a national microfinance strategy, create the National Microfinance Bank to preserve the rural branches of the former National Bank of Commerce, and prepare the National Microfinance Bank for privatization.

\section{Comparative Profiles}

17. The macroeconomic environments in Benin, Ghana, and Tanzania are typical of many African countries. More than two-thirds of the population live in rural areas in Tanzania, slightly more than in Benin and Ghana and above the 68 percent average for Sub-Saharan Africa (table 2). During the past 10 years each of the three countries has achieved gross domestic product (GDP) growth at average annual rates significantly higher than the rate of population growth rate, with the rate of growth of GDP accelerating in recent years. Also in all three countries the agriculture sector accounts for more than a third of GDP, with exports dominated by a single commodity (ginned cotton in Benin, cocoa in Ghana, and coffee in Tanzania), making them highly vulnerable to adverse changes in world prices for these commodities or declines in domestic production because of adverse weather conditions. Of the three countries Benin is the smallest in terms of total population and percentage of the population living in rural areas. All three have per capita income levels lower than the average for countries in Sub-Saharan Africa, although Benin's gross national income per capita is higher than that in Ghana and Tanzania. Gross national income per capita in Benin is three times higher than the estimated poverty line for the country, compared with two times for Ghana and Tanzania. A third of the total population falls below the national poverty line in Benin and Ghana, and slightly over 40 percent in Tanzania . 
Table 2. Selected Features of the Macroeconomic Environment, 2003

\begin{tabular}{|c|c|c|c|c|}
\hline Feature & Benin & Ghana & Tanzania & Sub-Saharan Africa \\
\hline Population (millions, 2002) & 6.6 & 20.3 & 35.2 & 689.3 \\
\hline Annual population growth (percent, 1995-2002) & 2.6 & 2.2 & 2.5 & 2.5 \\
\hline Annual labor force growth (percent, 2001-2010) & 2.8 & 2.0 & 2.0 & 2.2 \\
\hline Rural population (percent of total population), 2002 & 56.3 & 63.3 & 65.8 & 64.5 \\
\hline Gross national income (US\$ billions, 2003) & 2.5 & 5.5 & 9.7 & 310.9 \\
\hline Annual GDP growth rate (percent, 2001-2002) & 6.0 & 4.5 & 6.3 & 2.8 \\
\hline Gross national income per capita (US\$)a, 2002 & 380 & 270 & 290 & 450 \\
\hline Gross domestic savings/GDP (percent), 2002 & 6.0 & 10.3 & 9.7 & 18.5 \\
\hline Value added in Agriculture as a percentage of GDP, 2002 & 36.0 & 33.8 & 44.4 & 17.7 \\
\hline Principal commodity export & Ginned cotton & Cocoa & Coffee & - \\
\hline National poverty line (US\$ per person per year) & 131 & 138 & 143 & - \\
\hline Percent of population below national poverty line ${ }^{b}$ & 33 & 31.4 & 41.6 & - \\
\hline Depth of financial sector (percent)c, 2001 & 31.0 & 17.4 & 20.4 & 35.2 \\
\hline Credit provided by banking sector (percent)d, 2001 & 4.6 & 0.8 & 9.6 & 74.2 \\
\hline
\end{tabular}

- Not available.

a. Calculated using the Atlas method.

b. Benin-1995; Ghana-1992; Tanzania-1993.

c. M3/GDP.

d. Domestic credits provided by banking sector /GDP.

Source: World Bank: World Development Indicators 2003; African Development Indicators 2004

\section{STRUCTURE OF THE FORMAL FINANCIAL SYSTEM}

18. The financial sectors of Benin, Ghana, and Tanzania are relatively shallow: the degree of monetization of the economy as measured by the ratio of M3 to GDP is 31 percent for Benin, 17.4 percent for Ghana, and 20.4 percent for Tanzania - somewhat below the level for Sub-Saharan Africa. Moreover, domestic credit provided by the banking sector as a percentage of GDP is rather low in each of the three countries, and especially in Ghana. Each of the countries has undergone a period of restructuring and liberalization of the financial sector, wherein the government has privatized and reorganized banking institutions that it previously owned, controlled, and managed.

\section{Benin}

19. At the end of 2002, Benin's formal financial system consisted of a branch of the Banque Centrale des Etats de l'Afrique de l'Ouest (Central Bank of West African States or BCEAO), 7 private commercial banks, 2 leasing and credit institutions, 7 insurance companies, and more than 600 microfinance and savings and loans associations. In the last two years two of the seven commercial banks were newly licensed and started operations and two NBFIs were liquidated. All the older banks were created during the early 1990s. The government liquidated the three commercial banks it owned that were operating before this period following the collapse of the banking system as a result of the banking crisis of the late 1980s. The financial sector remains somewhat shallow, although at 26 percent the ratio of M2 to GDP is higher than for Ghana, Tanzania, and the average for Sub-Saharan Africa. In 2002 credit to the private sector stood at only 12 percent of GDP, total credit extended by MFIs was equivalent to 10 percent of total financial sector credit, and MFIs held an estimated 10 percent of total financial sector deposits. 


\section{Ghana}

20. The Ghanaian financial system comprises the Central Bank of Ghana, a stock exchange, 3 large foreign banks, 3 banks controlled by the public sector, and 10 small or medium-sized private sector banks. The 16 commercial banks have more than 300 branches throughout the country, and the Ghana Stock Exchange lists 21 companies. Ghana also has 115 RCBs, 3 discount houses, 2 building societies, 6 leasing companies, 8 finance companies, 9 deposit-taking savings and loan companies (S\&Ls), and some 200 credit unions. In 1999 the banking sector held more than two-thirds of total financial sector assets; however, the RCBs' total assets were equivalent to only 3 percent of banking sector assets. The banking sector is characterized by a high level of concentration. At the end of 1999 government-owned banks held some 31 percent of total banking sector assets (23 percent in one), while foreign banks accounted for 36 percent.

\section{Tanzania}

21. When Tanzania began to reform its financial sector 1991 the banking sector comprised the Central Bank of Tanzania, six deposit-taking financial institutions, and three specialized banks (investment, housing, and the postal system). The financial system has since expanded rapidly, and by the end of 1998 the country had 19 licensed commercial banks with 17 operating, 3 limited-license regional and community banks, 9 mostly privately-owned insurance companies, 4 state-owned pension funds, 105 foreign exchange bureaus, and some 650 urban and rural CFIs. Tanzania established a stock exchange in 1998, and, in contrast to Benin and Ghana, it has a formal deposit insurance system.

\section{FINANCIAL SECTOR REGULATORY FRAMEWORK}

\section{Regulatory and Supervisory Structure}

22. In Benin, Ghana, and Tanzania, as in many other developing countries, a general banking law regulates the business of banking, which is strictly defined as the taking of voluntary deposits from the general public and the intermediation of those deposits into loans and other investments at the discretion and risk of the financial intermediary (rather than of the depositor). The central bank supervisory authority responsible for carrying out the provisions of the law issues the general and specific guidelines and requirements for licensing and prudential supervision of entities licensed to carry out banking business.

\section{Benin}

23. Because Benin is a member of UMOA, its commercial banks and credit institutions are governed by the BCEAO (Law 90-018 of July 27, 1990) and the regional banking law and are subject to prudential supervision by the Regional Banking Commission. The regulatory framework for the financial sector is somewhat restrictive, in the sense that only licensed commercial banks, NBFIs, and CFIs can carry out financial intermediation. Before the advent of the regional microfinance law, commonly referred to as the PARMEC Law (PARMEC refers to the Projet d'Appui à la Réglementation sur les Mutuelles d'Epargne et de Crédit or Project to Assist the Regulation of Savings and Credit Cooperatives) in the UMOA countries in 1993, institutional providers of microfinance services operating in Benin and other UMOA countries were subject to several laws, including the Cooperative Law, the Usury Law, and the Banking Law. The authorities' desire to monitor a rapidly growing industry and to protect the industry's clients, especially depositors, led to the common standard for regulating the provision of microfinance services. However, despite the variety of other microfinance organizational formats that operated in UMOA countries the law only covered credit unions. Benin passed legislation in 1997 to implement the PARMEC Law, which closely emulates the regional model law. Under the PARMEC Law only credit unions and their network federation can be granted fully fledged licenses. Other non-mutualist MFIs are permitted to operate for five years within the rules defined by a convention-cadre, a standard agreement signed by the Ministry of Finance. The PARMEC Law excludes small and informal microfinance organizations, but provides for their voluntary formalization and registration. 


\section{Ghana}

24. The regulatory structure for Ghana's financial sector is characterized by a more conventional approach to prudential regulation of banking and financial institutions, wherein the central banking authority is a constitutionally autonomous and independent government agency. The regulatory framework for the tiered financial sector is more accommodating and inclusive than in Benin in that the banking and NBFI laws allow a range of banking institutions and NBFIs to engage in microfinance activities, even in the absence of a microfinance-specific regulatory framework. Until 2002 the Bank of Ghana divided prudential supervision activities between its Banking Supervision Department and Nonbank Financial Institutions Department. The latter's jurisdiction included certain financial institutions providing microfinance services, namely, deposit-taking S\&Ls and credit unions, but the Banking Supervision Department is now responsible for these entities and also oversees RCBs. A provision in Ghana's NBFI Law pertaining to the registration, licensing, and supervision of credit unions has never been applied, and is to be replaced by a separate credit union law that will divide these responsibilities between the Bank of Ghana and the Department of Cooperatives.

\section{Tanzania}

25. The Bank of Tanzania's Banking Supervision Directorate is responsible for prudential supervision of all licensed banking and financial institutions, while separate directorates are responsible for research and policy issues affecting different types of regulated banking and financial institutions. Tanzania's regulatory framework for the financial sector accommodates several tiers of banking institutions and NBFIs that can provide microfinance services, namely, commercial banks, regional and rural community banks, and CFIs. Under the revised 2003 Banking Law, the Bank of Tanzania is responsible for regulating and supervising all CFIs whose deposits have surpassed an amount equivalent to the minimum core capital for a microfinance company. Tanzania has only recently passed a package of specialized laws to serve as the regulatory framework for microfinance. The new regulatory framework could constrain the commercialization and scaling up of microfinance services by heretofore unregulated MFIs, especially NGOs and CFIs, if relatively high minimum capitalization requirements and financial accounting, auditing, and reporting requirements erect unduly steep barriers to entry. Nevertheless, the regulations and minimum capitalization requirements are still in draft and may help overcome the restrictions in the law if stakeholders' concerns are taken into account.

\section{Supervisory Capacity and Cost Considerations}

26. Three considerations are important in relation to prudential regulatory frameworks for microfinance institutions. One is the ongoing cost to the regulatory authority of supervising financial intermediaries much smaller than commercial banks, whose transactions differ significantly. ${ }^{2}$ An important issue is whether or not the regulatory authorities have the institutional capacity and staff resources to supervise microfinance institutions. The second consideration is the cost incurred in creating the institutional capacity to carry out regulatory oversight of microfinance activities and institutions, which includes developing a knowledge of and familiarity with microfinance transactions and the tools for measuring performance and recognizing danger signals in microfinance operations and markets. The third consideration pertains to the incremental costs to microfinance institutions of having the required organizational, technical, and staff resources to comply with reporting requirements and supervisory procedures. However, applying a guideline that the benefits of regulation should exceed its costs entails

Supervision entails costs not only for the regulator, but also for the regulated institution, as illustrated by the experience of credit unions and rural banks in Ghana. In Peru, supervision fees collected by the National Federation of Credit Unions of Peru are enough to inspect only 40 of its 130 member credit unions each year (Westley 2001). As a further example, the management of BancoSol in Bolivia estimates that complying with the bank superintendency's reporting requirements during its first year of operations (1992) generated a cost equivalent to 5 percent of the loan portfolio, even though this had declined to about 1 percent of the loan portfolio by 1999 (Christen and Rosenberg 2000). A third type of cost, the most difficult to measure but potentially also most important, is the cost of market intervention, i.e. compared to a state of perfect competition (sometimes called structural costs). Keeping financial institutions out of the market by imposing high barriers to entry is a good example for this. 
practical difficulties. These issues are discussed in the following paragraphs in terms of the structures in each of the countries studied.

\section{Benin}

27. Under the provisions of the PARMEC Law that governs all MFIs in UMOA countries, the supervision of microfinance is the responsibility of the ministry of finance in each country. The ministries are to conduct annual off-site and on-site supervision of MFIs, with the help of the BCEAO's Microfinance Department, if requested. The Microfinance Unit of Benin's Ministry of Finance was charged with supervising 85 licensed MFIs in 2001, even though many of them did not mobilize deposits from the public. By comparison, the BCEAO's Regional Banking Commission was responsible for 59 commercial banks in the UMOA region. Since the creation of the Microfinance Unit in 1998, it has only carried out 14 on-site inspections. Under the law, all licensed MFIs are required to submit their yearly financial statements to the Ministry of Finance; however, the law does not require MFIs to have their operations audited each year. The ministry can impose fines on MFIs that are late in submitting financial statements, but none has been levied thus far, implying a lack of enforcement of the rules. In 2000 the ministry received only 35 financial statements, representing a compliance rate of 41 percent, and did not sanction noncompliant licensed MFIs. The delegated supervision arrangement has not been achieving the intended results, and the Microfinance Unit is overwhelmed by the regulatory task. A proposed new arrangement, would entrust the BCEAO with direct supervision of the largest MFIs in UMOA, including FECECAM, the largest network of credit unions in Benin, thereby relie ving the Ministry of Finance of a heavy burden.

\section{Ghana}

28. In addition to off-site surveillance and on-site examination, the Bank of Ghana has a special pool of nine experienced commercial bankers that it can assign to rural banks to temporarily take over for bank managers so that they can take annual leave. A relief manager from the special pool spends an average of six weeks at a rural bank and uses the assignment to carry out a management audit of the rural bank and to test internal control and operating systems. While according to the NBFI Law the Bank of Ghana is responsible for the prudential supervision of credit unions, it has refrained from exercising that function because of a donor-financed project to strengthen the role of the apex body, the CUA. In the meantime, a proposed new credit union law is likely to result in delegating the primary prudential supervision of credit unions to the CUA, which would itself be licensed by the Bank of Ghana and report to a new credit union supervisory board that inclu des representatives of the Bank of Ghana and the Department of Cooperatives.

29. Enforcement mechanisms available to the Bank of Ghana include imposing fines or criminal sanctions, suspending bank activities or staff, revoking licenses, and appointing auditors and managers at distressed banks. Rural bank supervision is somewhat simplified by less cumbersome prudential reporting requirements, and the process has benefited from training programs organized by the Association of Rural Banks and the Ghana Micro Finance Institutions Network. Twenty-three supervisory staff oversee the 115 rural banks with assets of $\$ 518$ billion (US $\$ 69.1$ million), compared with the 30 supervisors assigned to oversee 17 major banks with assets of $\phi 14,436$ billion (US $\$ 1.9$ million). Supervision of RCBs takes about six staff-weeks per year and of S\&Ls about three or four staff-weeks per year (no data are available on the monetary costs).

30. Commercial banks, RCBs, and NBFIs do not pay explicit fees for supervision by the Bank of Ghana, although an indirect fee or tax is effectively collected through differential rates on liquidity reserves. Auditing fees for RCBs average around $₫ 10$ million (US\$1,300) per year. In 2000 on-site examinations covered 97 percent of rural banks, but reached 100 percent in 2001. Only about two-thirds of NBFIs were examined in 2000, but priority was given to deposit-taking NBFIs, and on-site examination of S\&Ls was 100 percent in 2000 and 2001. Thus far the Bank of Ghana has revoked the licenses of 23 rural banks.

31. Of 219 credit unions registered by the Department of Cooperatives in 2000, the CUA only considered 159 as fully fledged credit unions, with the remainder undergoing institutional development for full certification. A two-person team from the CUA and the Department of Cooperatives carries out annual examinations of credit unions, which takes a minimum of four days, and the credit unions are assessed a 
fee of $\phi 150,000$ (US\$20) per day or a minimum of $\phi 600,000$ (US\$80). The CUA's annual audit of credit unions covered 92 percent of credit unions in 2001.

\section{Tanzania}

32. The Banking Supervision Directorate, which has a total of 51 professional supervisors with an average of 10 years' experience each, is responsible for prudential supervision of licensed banks and NBFIs. The Banking Department has 29 supervisors, which covered close to 86 percent of all licensed banking and financial institutions in 2001. A full examination is conducted at least once a year for every commercial bank, NBFI, and community bank. On-site examination includes both head offices and all branch offices. Depending on a particular banking institution's problem, the Bank of Tanzania may also conduct targeted examinations of any commercial bank, NBFI, regional bank, or community bank as and when circumstances require. Examination takes an average of six weeks for large banks and three weeks for medium and small banks.

33. SACCOs, which comprise the CFI sector in Tanzania, must be inspected by district cooperative officers, and the registrar or assistant registrar must examine their final audited accounts. The Cooperative Audit and Supervision Corporation, a parastatal entity with offices in every region, carries out external audits of SACCOs' financial statements. A major problem of the SACCOs is that they tend not to use standard accounting procedures or to regularly maintain their records and do not comply with audit requirements.

\section{SIZE AND CHARACTERISTICS OF THE MICROFINANCE SECTOR}

34. Well-organized and nationally coordinated commercial microfinance is a relatively new development in Benin, Ghana, and Tanzania, and microfinance umbrella or network organizations have been organized only within the past few years. These consist of the Professional Association of Microfinance Practitioners (known as Alafia) in Benin, the Ghana Micro Finance Institutions Network (GHAMFIN), and the Tanzania Association of Micro Finance Institutions (TAMFI). In addition to undertaking policy advocacy and representation, accessing resources for and implementing institutional and staff capacity building programs, and offering a platform for the dissemination and exchange of best practices in microfinance, umbrella organizations have generally been instrumental in developing databases on their members' operations, outreach, and financial standing. Nevertheless, the umbrella organizations in Benin, Ghana, and Tanzania are struggling to compile statistical databases on their member MFIs that can quickly provide up-to-date overviews of each country's respective microfinance sector. The following subsections summarize the main types of MFIs and their characteristics in each of the countries studied.

\section{Benin}

35. Despite its relatively small size, Benin has the largest number of MFIs in the Union Monétaire Ouest Africaine (West Africa Monetary Union or UMOA) and a comparably diverse array of institutions. As of the end of 2001 the MFI sector had more than 600 retail organizations. around 700,000 clients, CFAF 30 billion (US\$40 million) in savings deposits, and CFAF 25 billion (US\$33.3 million) in outstanding loans. ${ }^{2}$ Organizations engaged in microfinance in Benin and the rest of UMOA are classified into three main categories: credit unions, credit-only MFIs, and donor projects with a microfinance component.

36. Credit unions' dominance of the microfinance industry is closely related to the evolution of Benin's formal financial sector, as the government encouraged the establishment of retail rural and microfinance organizations, including FECECAM, the largest credit union network, in response to the collapse of the banking sector in the late 1980s. By the end of 2001 FECECAM dominated the microfinance industry, holding 94 percent of savings deposits and 61 percent of total outstanding loans. The network had 298,000 member-shareholders in 96 primary-level credit unions, CFAF 20 billion (US $\$ 26.7$ million) in deposits, and CFAF 12 billion (US\$16 million) in outstanding loans.

\footnotetext{
2 The exchange rate used throughout this paper is US $\$ 1=$ CFAF 750
} 
37. Credit-only MFIs are the second largest player in Benin's microfinance industry, with each having more than CFAF 1 billion (US\$1.3 million) in total outstanding loans in 2001. These MFIs are FINADEV, the microfinance outlet of a commercial bank with CFAF 1.1 billion (US $\$ 1.5$ million) in outstanding loans; PADME, which provides microcredit to microenterprises and has outstanding loans of CFAF 6.8 billion (US\$9.1 million); and PAPME, which provides financial services to micro-entrepreneurs and small and medium enterprises and has outstanding loans of CFAF 7.1 billion (US\$9.5 million). Both PADME and PAPME were originally World Bank-supported projects, but are now independent nonprofit associations. By the end of 2001, credit-only institutions provided 34 percent of all loans in the microfinance industry.

38. Donor projects with a microfinance component are implemented through numerous small NGOs. Some are organized as credit unions, including the Fédération Nationale des Caisses Rurales d'Épargne et de Crédit (the National Federation of Rural Savings and Credit Cooperatives or FENACREP), the second largest network of credit unions in Benin, which was created in 1992 by the NGO Sasakawa Global 2000; the Projet d'Association et d'Entraide des Femmes (ASSEF), a women's self-help group project supported by the Swiss government that started in 1992 for women organized within small credit unions; and the Centre Béninois pour le Développement des Initiatives de Base (the Benin Center for the Development of Local Initiatives or CBDIBA), which was created by a French NGO to help set up a number of credit union MFIs such as Convergence 2000, as well non-credit union MFIs such as the Caisses Villageoises d'Epargne et de Crédit (CAVECA, village-level savings and credit associations). These projects represent less than 5 percent of the microfinance market in terms of outstanding loans.

39. Informal microfinance mechanisms in Benin include moneykeepers, moneylenders, rotating savings and credit associations or tontines, and the "yes-yes" system. ${ }^{3}$ Convergence 2000, a local NGO, has helped start a yes-yes system with the ultimate goal of transforming it into a formal microfinance organization.

\section{Ghana}

40. Ghana's formal and semiformal MFIs reach some 1.5 million members and depositors, of whom less than a third have loans. These MFIs include 115 RCBs with over a million recorded depositors and about 150,000 loan accounts (some of them groups of 5 to 35 members), 253 credit unions with over 120,000 members, and 9 S\&Ls with more than 160,000 depositors and 10,000 borrowers. Some 50 NGO MFIs reach a total of about 60,000 borrowers, but most of these (as well as even smaller community-based organizations) have fewer than 1,000 clients each. The Ghana Micro Finance Institutions Network, originally established in the late 1990s by a group of leading MFIs, cuts across formal, semiformal, and informal institutions, and is being restructured as an umbrella body governed by representatives of their respective associations. The objectives of the Ghana Micro Finance Institutions Network include serving as a knowledge center for the industry and monitoring and benchmarking industry performance.

41. Rural and community banks. During the 1990s some of the RCBs adopted a more commercial approach and introduced innovative programs, often in collaboration with NGOs that offered proven microfinance methodologies, such as Freedom from Hunger's Credit with Education program. A few RCBs have succeeded in expanding to more than 20,000 clients and reaching high levels of operational and financial sustainability. ${ }^{4}$ On average, however, Ghana's RCBs are relatively small compared even with African MFIs, especially in terms of lending, though many have become relatively profitable mainly because of high interest rates on treasury bills and high reserve requirements that forestalled risky lending (table 3 ).

3 The yes-yes system (referred to as susu collectors in Ghana) allows a client to save regularly via an informal, individual money collector who collects a daily amount fixed by the client and returns the accumulated sum minus one day's deposit as a fee at the end of the month. Collectors sometimes extend loans to their clients by advancing the monthly total.

4 For example, in 1998 the Nsoatreman Rural Bank was reported to have 25,587 depositors with an average balance of US $\$ 38,17,584$ borrowers with an average loan size of US\$190, 130 percent operational self-sufficiency, and portfolio in arrears of less than 4 percent. 
Table 3. Comparison of Ghana's Rural Banks and Credit Unions with African MFIs, End of 2000

\begin{tabular}{|c|c|c|c|}
\hline Indicator (average) & African MFIs ${ }^{a}$ & Ghanaian rural banks & Ghanaian credit unions \\
\hline Number of clients & 7,374 & 8,488 & 405 \\
\hline Average loan balance outstanding per client (US\$) & 119 & 30 & 153 \\
\hline Total loan portfolio (US\$) & 690,027 & 251,924 & 65,180 \\
\hline Total assets (US\$) & $1,612,029$ & 841,102 & 110,961 \\
\hline Capital/assets (percent) & 60.3 & 2.6 & 3.5 \\
\hline Return on assets (percent) & -16.1 & 4.4 & n.a. \\
\hline
\end{tabular}

n.a. Not applicable.

Note: Ghanaian S\&Ls are not included.

a. Leading MFIs that report to the MicroBanking Bulletin.

Source: Kowubaa, Ltd. (2000, p. 60).

42. Savings and loan companies. The first S\&L license went to Women's World Banking Ghana in 1994, representing the first transformation of an NGO into a licensed financial institution. Its success, however, has been limited, and a number of S\&Ls are suffering from portfolio problems and having difficulty complying with central bank regulations. Some of them represent entrepreneurs with little experience in financial services, but with surplus funds and high motivation. Sinapi Aba Trust is expected to become the second transformed NGO, and EMPRETEC, an NGO that provides excellent training for microenterprises and small businesses, is also trying to meet the paid-up capital requirement needed to be licensed as an S\&L.

43. Credit unions. The past weak financial performance of credit unions has been due in large part to their organization as cooperative societies with a welfare focus, and in particular to their policy of low interest rates. In recent years Ghana's Cooperative Credit Union Association (CUA) has moved to improve the commercial orientation and financial reporting of its primary societies, as well as its own financial sustainability. The CUA is an innovator in providing both credit insurance, which pays off the outstanding loan balance in case of the death of a borrower, and a contractual savings program, which matches savings, up to a limit, if held at death or to maturity. Nevertheless, Credit unions are relatively small, with an average of 400 to 500 members per society, although theUS $\$ 153$ average loan size is well above that for African MFIs, as well as for RCBs.

44. Since 1989 the government has launched several special credit schemes, usually at subsidized rates, that have generally reached few people and have had extremely poor recovery rates. Microcredit schemes have also been used in poverty alleviation programs and the district assembly common funds. In 2001 the government launched the Emergency Social Relief Project to provide US\$57 million in business loans during 2002-04 to the economically active poor at a 20 percent annual interest rate. The RCBs and NGOs through which disbursements are made often do not have autonomy in selecting the beneficiaries. The main threat to sustainable microfinance from these government programs comes from the negative effects on MFIs' efforts to mobilize savings and to collect on loans from borrowers whose willingness to repay is typically low when they perceive loans as coming from government or donor funds at subsidized rates.

\section{Tanzania}

45. The principal institutional providers of microfinance services include the National Microfinance Bank and two other commercial banks that have established internal divisions dedicated to microfinance, the Tanzania Postal Bank and three regional and rural unit banks that fall under the NBFI category; urban-

5 This is probably because 59 percent of the credit unions are workplace based, with 71 percent of the CUA's membership serving a more middle-class, salaried clientele than the community-based ones. 
and rural-based CFIs, and a number of microcredit programs supported by international donors through NGO MFIs. ${ }^{6}$

46. Licensed banks. The microfinance-focused operations of the National Microfinance Bank and the other regular commercial banks are fairly new start-ups, and outreach is low to date. The National Microfinance Bank's advantage consists of its network of 104 branches through which microfinance operations can be run, but fewer than 20 branches have so far been prepared to offer microfinance services. Some 2,810 loans are outstanding out of the 5,072 loans that have been disbursed since August 2000, and the outstanding loan portfolio stood at T Sh 907.5 million (US\$1.134 million) at the end of $2001 .^{7}$ The National Microfinance Bank has a fairly large base of savings and time deposits: about T Sh 70 billion (US\$87.5 million) in outstanding savings deposits from 670,000 accounts as of the end of 1999 (Bank of Tanzania 2001). The average savings deposit balance is about T Sh 105,000 (US\$130) per account.

47. Postal Bank. The main objective of the Tanzania Postal Bank has been to mobilize local savings and promote the savings habit among small-scale savers, particularly individuals. It provides savings deposit services in all post offices. As of the end of 2000 the Tanzania Postal Bank had slightly more than 1 million deposit accounts serviced through a network of 4 branches and 15 operating units based in larger units of the postal administration, which has 121 post offices and stations throughout the country.

48. Regional and community banks. Tanzania has lower-level tiers of licensed banking institutions-the regional bank category and the rural unit community bank category-meant to encourage the transformation of NGO MFIs to licensed status. Nevertheless, despite the reasonably low minimum capitalization requirement levels, only three banks fall into the regional or rural unit community bank categories, and both policymakers and microfinance practitioners need to examine and assess the factors underlying this state of affairs. To some extent these lower-level banking tiers are similar to those in Ghana, which has seen a larger number of participants in lower tiers. As with a significant segment of Tanzania's microfinance industry, operating and financial information on the regional and rural unit community banks are not readily available.

49. SACCOs constitute the largest segment of Tanzania's microfinance industry. The total membership base of SACCOs is some 130,000, with urban SACCOs accounting for 47,000 members and rural SACCOs for some 83,000 as of the end of 2000. Total members' funds amounted to US\$17 million equivalent, with the bulk of both members' shares (US $\$ 4.7$ million) and members' deposits (US\$9.4 million) coming from the urban SACCOs. Rural SACCOs had an average of US\$34 in shares and deposits per member, about $1 / 10$ th the average per urban SACCO member

50. NGOs. Among the larger microfinance NGOs in terms of outreach and client base at the end of 2001 were the Mennonite Economic Development Association, which uses the individual lending methodology in catering to about 4,000 micro-entrepreneurs, ${ }^{8}$ and the Promotion of Rural Initiatives and Development Enterprises (PRIDE)-Tanzania, which is affiliated with the Kenya-based PRIDE-Africa and uses the solidarity or group-based lending methodology. A former government-led program, the Presidential Trust Fund, was privatized in 2000 and has been operating as a microfinance NGO. The Presidential Trust Fund has five branches through which its client base of 8,000 can access microfinance loans under a group lending approach. Tanzania has a number of other NGO-based microfinance loan programs, such as the Foundation for International Community Assistance-Tanzania (FINCA), which are supported by international donor agencies and networks, but operational and market outreach data are not easily available.

6 A unit bank is an institution that is licensed/authorized to operate only from one office location.

7 The exchange rate for Tanzanian Shillings used throughout this paper is US $\$ 1=\mathrm{T}$ Sh 800 .

8 The Mennonite Economic Development Association sold its operations to the National Microfinance Bank in 2002. 


\section{FRAMEWORK FOR R EGULATING MICROFINANCE}

\section{BASIC FEATURES OF THE REGULATORY FRAMEWORKS}

51. The three countries in the study have similar prudential regulatory frameworks for banking institutions and divergent regulatory regimes for non-bank and NGO MFIs and for membership-based CFIs. Banking institutions are subject to licensing and full prudential supervision, which may be defined as off-site monitoring and reporting and on-site examination to ensure compliance with stipulated prudential standards for activities, operations, fitness and propriety of directors and officers, and internal governance.

52. A country's legal and regulatory framework governs microfinance services and their institutional providers and specifies the activities, services, and products that are subject to regulation; the manner in which they may be offered; the institutions that can provide them; and the legal relationships and package of rights, responsibilities, and remedies between providers and recipients of transactions. A legal and regulatory framework that permits sustainable microfinance consists of several components: (a) the microfinance law; (b) the implementing administrative regulations; (c) the related laws and regulations; and (d) the executing administrative agencies, properly staffed and organized. The key features by category of institution are summarized as follows":

- Informal providers of microfinance services, such as rotating or accumulating savings and credit associations, are neither registered nor regulated. Semiformal providers generally consist of institutional providers of microfinance services that are dependent on other people's money, that is, grant funds from donors and government programs. They are legally registered, but in Ghana and Tanzania, as in most other countries, they are not regulated or supervised. These institutional providers are mainly multipurpose NGOs engaged in microcredit, usually organized as nonprofit foundations or associations. However, Benin requires entities funded by donor grants, such as PADME and PAPME, to be registered, licensed, and prudentially regulated under a convention-cadre agreement with the Ministry of Finance.

- Credit unions in Benin that are funded by members' capital contributions and savings deposits must be registered, licensed, and prudentially regulated under the provisions of the PARMEC Law, including both primary-level credit unions and second-tier CFI federations such as FECECAM and FENACREP. In contrast, primary-level CFIs in Ghana and Tanzania and their second- and upper-tier federation associations - the CUA in Ghana, the Savings and Credit Cooperative Union League of Tanzania, and the Tanzania Federation of Cooperatives - are registered with the Department of Cooperatives and regulated under the provisions of the respective countries' laws on cooperatives. Unlike in Benin, the central bank supervisory authority does not prudentially supervise these CFIs.

- MFIs funded by shareholders' capital funds and retail public deposits, i.e., commercial banks in Tanzania, RCBs in Ghana, and NBFIs (regional banks, rural unit community banks, and the Postal Bank in Tanzania and deposit-taking S\&Ls in Ghana), are subject to registration, licensing, and full prudential regulation by the central banking supervisory authority. Benin currently does not have any commercial banks or NBFIs directly involved in retail microfinance, except for FINADEV, a microfinance subsidiary of a commercial bank.

53. Entities that provide microcredit services to micro and small enterprises and low-income households in the countries studied are typically organized as civil society nonprofit institutions (NGOs). When the laws of the countries under which they are established do not expressly permit or prohibit extending small amounts of often unsecured loans using other people's money (grants and donations), there may be some ambiguity about the practice of charging commercial rates of interest on loans under a tax-exempt status as a nonprofit organization. Thresholds levels of microfinance intermediation activities which subject MFIs to regulation are as follows:

9 The distinguishing features of the standard legal framework for different types of organizations that provide microfinance services are highlighted in an Appendix table. 
- NGOs involved in microfinance in Benin, Ghana, and Tanzania are registered legal entitie s. In Ghana and Tanzania such NGOs are not subject to any forms of nonprudential or prudential supervision and generally provide microcredit services only. Any deposits they take from borrowers are in the form of nonvoluntary security deposits, which the NGO returns to the borrowers when they have paid off their loans or retains as security against further loans. Benin's PARMEC law requires both membershipbased credit unions and non-credit union microfinance NGOs to be registered and licensed. ${ }^{10}$

- Taking voluntary deposits from the public on a retail basis for intermediation into loans and investments at the risk of the intermediating institution activates different thresholds of regulatory oversight and prudential supervision in different countries. In all three countries the business of mobilizing and intermediating deposits from the public is reserved exclusively for institutions that have been specifically organized for banking and finance and have obtained the required license from the central banking authority. ${ }^{11}$ The licensing and authorization procedures usually stipulate minimum capitalization requirements at entry and subsequent compliance with various prudential standards and requirements, as summarized in table 4.

- Each of the countries has banking and NBFI categories, but Ghana and Tanzania have more than one tier of licensed banking institutions that offer microfinance as a specialized niche as well as commercial banks that have dedicated microfinance operations.

Table 4. Thresholds of Intermediation Activities Subject to Regulation and Licensing, 2002

\begin{tabular}{|c|c|c|c|}
\hline Type of institution & Benin & Ghana & Tanzania \\
\hline NGO MFIS & $\begin{array}{l}\text { Providing microcredits to clients } \\
\text { (must secure authorization from } \\
\text { Microfinance Unit, Ministry of } \\
\text { Finance; no MCR is required) }\end{array}$ & Not subject to regulation & Not subject to regulation \\
\hline $\begin{array}{l}\text { Cooperative Financial } \\
\text { Institutions (CFIs) }\end{array}$ & $\begin{array}{l}\text { Taking deposits from and making } \\
\text { loans to members (no MCR is } \\
\text { required). }\end{array}$ & $\begin{array}{l}\text { Subject to registration and } \\
\text { regulation by the Department of } \\
\text { Cooperatives (no MCR is } \\
\text { required). }\end{array}$ & $\begin{array}{l}\text { Subject to registration and regulation } \\
\text { by the Department of Cooperatives } \\
\text { (no MCR is required). }\end{array}$ \\
\hline Other NBFIs & None involved in microfinance & $\begin{array}{l}\text { Taking savings deposits and } \\
\text { making microloans (MCR is US\$2 } \\
\text { million for S\&LS) }\end{array}$ & No NBFIs involved in microfinance \\
\hline $\begin{array}{l}\text { Limited-service } \\
\text { specialized banks }\end{array}$ & $\begin{array}{l}\text { Taking deposits from and making } \\
\text { loans to clients via convention- } \\
\text { cadre (no MCR is required). }\end{array}$ & $\begin{array}{l}\text { Taking savings deposits and } \\
\text { making microloans (MCR for } \\
\text { RCBs is US } \$ 20,000)\end{array}$ & $\begin{array}{l}\text { Taking savings deposits and making } \\
\text { microloans(MCR is } \$ 250,000 \text { for } \\
\text { regional banks and US } \$ 62,500 \text { for } \\
\text { rural unit banks) }\end{array}$ \\
\hline $\begin{array}{l}\text { Full service commercial } \\
\text { banks }\end{array}$ & $\begin{array}{l}\text { None directly involved in retail } \\
\text { microfinance } \\
\text { Making wholesale loans to and } \\
\text { taking deposits from other MFIs }\end{array}$ & None involved in microfinance & $\begin{array}{l}\text { Full service deposits, checking, and } \\
\text { savings; commercial bank license } \\
\text { from the Bank of Tanzania is required } \\
\text { (MCR is US\$1.25 million) }\end{array}$ \\
\hline
\end{tabular}

MCR Minimum capitalization requirements.

a. Some reports group regional banks and rural unit banks under the NBFI category.

Source: Gallardo and Randhawa (2003); Ouattara (2003); Steel and Andah (2003).

10 In South Africa any registered legal entity that extends personal microloans of less than R 10,000 for less than 36 months at interest rates above the Usury Law ceiling is required to register with the Micro Finance Regulatory Council and secure prior authorization and exemption from the Usury Act. This regulation applies to a diverse range of financial institutions, including NGOs, commercial banks, and CFIs.

11 Ghana's banking laws define "public" as 20 or more persons (legal or natural), and exclude small, informal, commonbond groups. 


\section{PRUDENTIAL STANDARDS FOR LICENSED MFIS}

54. The key prudential standards imposed by regulatory agencies of Benin, Ghana, and Tanzania on licensed institutional providers of microfinance services consist of minimum capitalization requirements and capital adequacy levels, asset quality standards, limits on risk exposure, and liquidity management guidelines. The following subsections discuss the different standards.

\section{Minimum Capitalization Requirements}

55. Minimum capitalization requirements (MCR) are intended to ensure an adequate financial cushion for institutions' operations and serve to restrict entry to licensed entities permitted to mobilize and intermediate deposits from the public. From the perspective of the financial systems approach, MCR should be set at levels that would enable MFIs to become integrated with the formal financial system while maintaining prudential standards. Applying the same MCR as for commercial banks could be considered an excessive barrier to entry, given the generally smaller scale and restricted scope of operations of MFIs . However, setting the MCR too low risks excessive entry relative to the supervisory authorities' capacity to enforce prudential standards and the MFIs' capacity to sustain successful intermediation of deposits.

56. The MCR should be viewed as a primary tool for rationing scarce regulatory and supervisory resources available to the regulators and supervisors, rather than as an instrument for promoting and propagating the entry of new intermediaries into microfinance. The setting of MCR levels should balance the objective of opening the formal financial system to MFIs with a realistic assessment of how many additional deposittaking MFIs the relevant authorities would be able to prudentially supervise with a reasonable capacity building program and how many MFIs would be likely to enter at different MCR levels.

57. The MCR for specialized banks and microfinance-oriented NBFIs in Ghana and Tanzania have generally been low enough to encourage the establishment and operation of microfinance providers as licensed institutions with the authorization to mobilize savings and time deposits from the community at large. However, as table 5 shows, recent changes are more restrictive.

Table 5. Minimum Capital and Adequacy Requirements for Licensed MFIs, 2002

\begin{tabular}{|c|c|c|c|}
\hline Requirement & $\begin{array}{c}\text { Benin: } \\
\text { credit unions and authorized } \\
\text { MFls } \\
\end{array}$ & $\begin{array}{c}\text { Ghana: } \\
\text { licensed banks, } \\
\text { NBFls, and credit unions }\end{array}$ & $\begin{array}{c}\text { Tanzania: } \\
\text { licensed banks and MFIs }\end{array}$ \\
\hline Minimum capital & No minimum level required & $\begin{array}{l}\text { Rural banks: US } \$ 67,000 \\
\text { S\&Ls: US } \$ 2 \text { million since } 2001 \text {, } \\
\text { up from US } \$ 15,000 \text { to - } \\
\text { US } \$ 22,000 \text { during 1993-99 }\end{array}$ & $\begin{array}{l}\text { - } \text { Commercial banks: US } \$ 5 \\
\text { million } \\
\text { - Regional banks: US } \$ 250,000 \\
\text { - Rural banks: US } \$ 62,500 \\
\text { Microfinance companies: } \\
\text { US } \$ 1.25 \text { million (stipulated } \\
\text { by new law) }\end{array}$ \\
\hline $\begin{array}{l}\text { Capital adequacy (capital } \\
\text { as a percentage of risk } \\
\text { assets) }\end{array}$ & No minimum ratio specified & $\begin{array}{ll}\text { - } & \text { Rural banks: } 6 \% \\
\text { - } & \text { S\&Ls: } 10 \% \\
\text { - } & \text { Credit unions: } 10 \%\end{array}$ & $6 \%$ \\
\hline
\end{tabular}

a. Data for Tanzania are as June 2003.

Source: Gallardo and Randhawa (2003); Ouattara (2003); Steel and Andah (2003).

58. Benin's licensing framework does not prescribe MCR for the licensed credit unions or for the non-credit union MFIs authorized to operate by the Ministry of Finance. In Ghana, the MCR is only a modest hurdle for RCBs, but no longer for S\&Ls. The recent increase in MCR to US\$2 million is 15 times the 1998 level in local currency. In part, this increase reflects concerns by the supervisory authorities about the failure of many S\&Ls to meet prudential standards and about their own capacity to handle the growing number of applications for new entrants. The MCR now constitutes a significant barrier to entry and 
corresponds to about 60 percent of the capitalization required for domestic banks. ${ }^{12}$ Ghanaian credit unions are not subject to MCR. For Tanzania, the minimum capitalization requirements for regional banks and rural community banks appear to be at fairly accessible levels for investors in and promoters of institutional microfinance. The response, however, has been limited: only one regional bank and two rural community banks have been organized. The recently enacted Law on Microfinance Companies appears unlikely to foster significant new entry, as the currently unregulated or unlicensed MFIs are unlikely to achieve the stipulated (but still being discussed) MCR of T Sh 1 billion. Tanzanian credit unions are not subject to MCR.

\section{Capital Adequacy}

59. In Ghana, the capital adequacy standard (CAR) prescribed for banks, including rural banks, is 6 percent of risk assets. A higher standard of 10 percent of risk assets is prescribed for S\&Ls and deposit-taking NBFIs. The Ghana Credit Union Association follows the World Council of Credit Unions standard of 10 percent of total assets. In Tanzania, regional banks and rural community banks are subject to a uniform CAR of 6 percent of risk assets. No prudential standards for capital adequacy are imposed on credit unions in Benin, Ghana, and Tanzania other than voluntary norms recommended by international CFI networks. As credit unions in Benin, Ghana, and Tanzania are not subject to minimum capitalization requirements, consistent with international practices that allow easy entry for member-based CFIs, this puts the burden of prudential regulation on the maintenance of CAR, for which measurement and standards should be similar for CFIs and for banking institutions.

60. The CAR applicable to licensed MFIs in Ghana and Tanzania appear to be lower than is prudent, especially because shareholders of MFIs generally have difficulty in quickly responding to calls for additional capital infusion. For a number of reasons (see Christen and Rosenberg 2000), self-sufficient MFIs (other than rural banks) in the Microfinance Information Exchange database maintain a higher ratio of capital funds to total assets compared to commercial banks, ranging from 17 percent for rural banks, 24 percent for regular banks, 31 percent for CFIs, and 40 percent for non-bank MFIs.

\section{Asset Quality}

61. In principle, recognizing and setting aside provisions for delinquent loans should be handled more aggressively for MFIs than for commercial banks, given the relatively short-term nature and unconventional collateral typical of microfinance portfolios. Benin, Ghana, and Tanzania vary significantly in how they classify loans as delinquent and in how they provision for possible losses. Only Benin requires provisioning at the time a loan is classified as delinquent, that is, when a payment is overdue by 90 days or more. A loan is delinquent when overdue by 31 days or more in Tanzania, but provisioning is required only when a loan is overdue by more than 180 days. Ghana is the most restrictive, classifying a microfinance loan as delinquent when a scheduled payment is 1 day overdue and requiring provisioning after 60 days. Provisioning at 40 percent is required when a loan is delinquent for a period between 61 and up to 90 days in Ghana and for 181 days or more in Tanzania. Provisioning at 100 percent is required when a loan is delinquent for 151 or more days in Ghana, and for 360 days or more in Benin and Tanzania (table 6). ${ }^{13}$

Table 6. Asset Quality Standards for Licensed MFIs, 2002

12 This capital adequacy ratio may be more appropriate for other categories of NBFIs that book considerably more assets than the typical S\&L (or NGO). In general, Ghanaian rural banks and S\&Ls have faced difficulties in raising additional funds from shareholders to meet increased paid-in capital requirements. Nevertheless, a new specialized MFI with international funding has been able to raise sufficient capital to become licensed, although the Ghanaian ownership share dropped from 25 to 2.5 percent following the increase in the capital requirement.

${ }^{13}$ Global best practice in microfinance is not rigid and allows for some degree of flexibility based on the maturity profiles and amortization periods of different categories of microfinance loans. For instance, for microfinance loan categories with average maturities of 180 days and with amortization payments scheduled every two weeks (or 15 days), none of the full or 100 percent provisioning guidelines for Benin, Tanzania, or even Ghana would make sense or be considered prudent business practice, because the period of loan delinquencies would have exceeded the original maturity dates and amortization payment schedules. 


\begin{tabular}{|c|c|c|c|}
\hline Item & $\begin{array}{l}\text { Benin: } \\
\text { credit unions and } \\
\text { authorized MFIs } \\
\end{array}$ & $\begin{array}{c}\text { Ghana: } \\
\text { licensed banks, } \\
\text { NBFls, and credit unions }\end{array}$ & $\begin{array}{c}\text { Tanzania: } \\
\text { licensed banks }\end{array}$ \\
\hline Classification of loan as delinquent & $=90$ days & 1 day overdue & $=31$ days \\
\hline $\begin{array}{l}\text { Provisioning at } 40 \text { percent or more } \\
\text { for delinquent loans }\end{array}$ & $=90$ days & $>60$ days but $<90$ days & $=181$ days \\
\hline $\begin{array}{l}\text { Provisioning at } 100 \text { percent for } \\
\text { delinquent loans }\end{array}$ & $=360$ days & $>150$ days & $=360$ days \\
\hline Reserve for loan losses & n.a. & $\begin{array}{l}1 \text { percent general reserve }+ \text { specific } \\
\text { loan provisions(basket basis) }\end{array}$ & $\begin{array}{l}2 \text { percent general reserve }+ \\
\text { specific loan provisions }\end{array}$ \\
\hline General reserve & $\begin{array}{l}15 \text { percent of net income } \\
\text { annually }\end{array}$ & 1 percent of loans outstanding & $\begin{array}{l}2 \text { percent of loans } \\
\text { outstanding }\end{array}$ \\
\hline
\end{tabular}

n.a. Not applicable.

Source: Gallardo and Randhawa (2003); Ouattara (2003); Steel and Andah (2003).

\section{Risk Exposure Limits}

62. Benin, Ghana, and Tanzania have stringent ceilings based on an institution's net worth with respect to loans to any single borrower as well as for connected lending (table 7). The prudential standards that are particularly restrictive for institutions providing microfinance services are the ceilings on unsecured loans in Ghana and Tanzania and on fixed assets in Tanzania. Ghana has no aggregate ceiling on unsecured loans, but the single borrower limit for unsecured loans is 10 percent of net worth. Licensed banks in Tanzania are subject to a ceiling on fixed assets, set at 10 percent of net worth, and a ceiling on unsecured loans set at 5 percent of net worth (the new Law on Microfinance also places a single borrower limit of 1 percent of core capital on unsecured loans).

63. These regulations constrain downscaling by commercial banks into microfinance and inhibit MFIs from seeking licensed/prudentially supervised status, because virtually all microfinance loans are unsecured as the term is defined in manuals of regulations and prudential standards issued by central bank supervisory authorities. Third party personal guarantees; informal or semiformal security pledges on movable collateral, for example, small equipment; and similar methods MFIs typically use to secure loans do not qualify as acceptable collateral or security for loan obligations under conventional prudential standards. Furthermore, microfinance loans will not meet loan documentation standards required under currently accepted conventions, because most microfinance borrowers cannot present audited financial statements or operating records for the micro-enterprises and small businesses they operate. ${ }^{14}$

${ }^{14}$ To accommodate microfinance lending activities by licensed institutions, the Philippine Central Bank has undertaken a series of moves intended to recognize the fundamental structure of a microfinance loan by defining what it will recognize as loans for microfinance and adjusting the applicable manuals of regulations for and reporting on microfinance loans. One result is that the risk weighting of unsecured microfinance loans relative to core capital is 75 percent instead of the 100 percent for unsecured commercial loans. 
Table 7. Risk Exposure Limits Imposed on Licensed MFIs, 2002

\begin{tabular}{|c|c|c|c|}
\hline Item & $\begin{array}{c}\text { Benin: } \\
\text { credit unions and authorized } \\
\text { MFls }\end{array}$ & $\begin{array}{c}\text { Ghana: } \\
\text { licensed banks, NBFls, } \\
\text { and credit unions }\end{array}$ & $\begin{array}{c}\text { Tanzania: } \\
\text { licensed banksa }\end{array}$ \\
\hline Ceiling on total loans & 200 percent of total deposits & No ceiling specified & No ceiling specified \\
\hline Unsecured loans ceiling & No ceiling specified & No ceiling specified & 10 percent of core capital \\
\hline Single borrower limit & 10 percent of total deposits & $\begin{array}{l}\text { Unsecured loans: } 10 \text { percent of } \\
\text { net worth } \\
\text { Secured loans: } 25 \text { percent of net } \\
\text { worth for banks; } 15 \text { percent of net } \\
\text { worth for NBFIs and S\&LS }\end{array}$ & 25 percent of core capital \\
\hline Connected lending limit & 20 percent of total deposits & 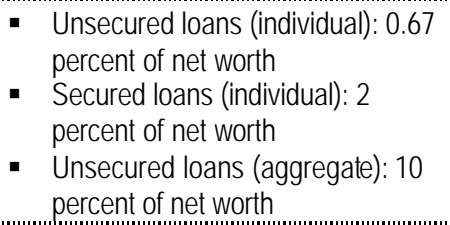 & $\begin{array}{l}\text { Less than or equal to the value of the } \\
\text { officer's shares and deposits; in total } \\
\text { less than or equal to } 25 \text { percent of the } \\
\text { bank's net worth }\end{array}$ \\
\hline Ceiling on fixed assets & No ceiling specified & No ceiling specified & 10 percent of net worth \\
\hline
\end{tabular}

a. Data for Tanzania are as of June 2003.

Source: Gallardo and Randhawa (2003); Ouattara (2003); Steel and Andah (2003).

\section{Liquidity Risk}

64. Credit unions and licensed MFIs in Benin and licensed banks, and deposit-taking NBFIs in Ghana and Tanzania are required to maintain primary liquidity reserves against deposit liabilities. The requirement is 15 percent of total deposits in Benin and 20 percent of demand deposits in Tanzania (table 8). A related requirement in Tanzania is that total loans may not exceed 80 percent of total deposits. For S\&Ls in Ghana the primary reserve is 10 percent, plus a 15 percent secondary reserve on total deposits. Ghana's Credit Union Association requires member credit unions to maintain a 10 percent reserve on deposits. In an effort to improve the solvency of rural banks in Ghana, the secondary reserve requirement on total deposits was raised to 52 percent in 1996, in addition to the 10 percent primary reserve requirement. By restricting risky loans and forcing investment in treasury bills with high interest rates (more than 30 percent per year), this restraint helped raise the number of rural banks rated as satisfactory. Nevertheless, it severely hampered their ability to serve their intended rural clientele, and the authorities subsequently lowered the secondary reserve requirement to 20 to 30 percent in 2002, depending on the loan recovery rate of each individual rural bank. Credit unions and licensed MFIs in Benin must comply with a specified liquidity ratio, namely, current assets must not exceed 80 percent of current liabilities, and a maturity matching standard, where medium- to long-term assets must be fully covered by matching medium- and long-term liabilities. This is a fairly difficult standard to meet because of the dearth of medium- to longterm deposits or borrowed funds in Benin as in many other developing countries. 
Table 8. Liquidity Reserve Requirements for Licensed MFIs, 2002

\begin{tabular}{|c|c|c|c|}
\hline Item & $\begin{array}{l}\text { Benin: } \\
\text { credit unions and } \\
\text { authorized MFIs }\end{array}$ & $\begin{array}{c}\text { Ghana: } \\
\text { licensed banks, NBFIs, } \\
\text { and credit unions }\end{array}$ & $\begin{array}{c}\text { Tanzania: } \\
\text { licensed banks }\end{array}$ \\
\hline Required reserves & 15 percent of total deposits & $\begin{array}{l}\text { - } \text { Rural banks: } 6 \text { percent } \\
\text { - } \quad \text { S\&Ls: } 10 \text { percent } \\
\text { - } \quad \text { Credit unions: } 10 \text { percent }\end{array}$ & 20 percent of demand deposits \\
\hline Secondary reserves & n.a. & $\begin{array}{l}\text { Rural banks: } 52 \text { percent of total } \\
\text { deposits } \\
\text { - S\&Ls: } 15 \text { percent of total } \\
\text { deposits }\end{array}$ & No prudential standard specified \\
\hline Liquidity ratio & $\begin{array}{l}\text { Current assets must not exceed } \\
80 \text { percent of current liabilities }\end{array}$ & No prudential standard specified & $\begin{array}{l}\text { Total loans may not exceed } 80 \\
\text { percent of deposits }\end{array}$ \\
\hline $\begin{array}{l}\text { Asset:liability matching of } \\
\text { medium- and long-term } \\
\text { liabilities to medium- and } \\
\text { long-term assets }\end{array}$ & 100 percent & No prudential standard specified & No prudential standard specified \\
\hline
\end{tabular}

n.a. Not applicable.

Source: Gallardo and Randhawa 2003; Ouattara 2003; Steel and Andah 2003.

\section{Prudential Surveil lance}

65. The tools and mechanisms for prudential surveillance are fairly similar in the three countries: making use of external auditors to review financial operations and reports, requiring the submission of periodic reports on operations and financial results, and having supervisory staff carry out on-site examinations and audits. The exception is Benin, where credit unions and licensed MFIs are not required to have their financial statements and certification examined by external auditors.

\section{Deposit Protectio $n$}

66. Explicit deposit insurance has been spreading rapidly in recent years, even to countries with relatively low levels of financial and institutional development. As some of the empirical literature points out, differences in deposit insurance design may affect discipline in private financial markets, banking stability, financial development, and the efficacy of crisis resolution measures. The primary goals of a deposit insurance system are to contribute to the stability of a country's financial system and to protect less financially sophisticated depositors from losing their deposits when banks fail. The recently completed work of the Financial Stability Forum's Working Group on Deposit Insurance underscores the following three main findings (Bank for International Settlements 2001):

- An explicit deposit insurance system is preferable to implicit protection if it clarifies the authorities' obligations to depositors and limits the scope for discretionary decisions that may result in arbitrary actions.

- A deposit insurance system needs to be properly designed, well implemented, and understood by the public in order to be credible and to avoid moral hazard.

- A deposit insurance system needs to be part of a well-designed financial safety net that is supported by strong prudential regulation and supervision, effective laws that are enforced, and sound accounting and disclosure regimes.

67. The existence and operation of an explicit deposit insurance system can provide supplementary regulation and supervision of institutions that are licensed to accept deposits from the public, to the extent that the entity providing deposit insurance has the legal power to examine and evaluate the financial and operational soundness of banking and financial institutions with insured deposits. The supplemental examination and evaluation is usually separate from the prudential supervision of the central bank or supervisory authority, as in the case of the Philippines and Tanzania. For purposes of comparison, table 9 
presents deposit insurance profiles for these two countries and for Equatorial Guinea, Kenya, and Uganda. $^{15}$

Table 9. Formal Deposit Protection Structures, Selected Countries

\begin{tabular}{|c|c|c|c|c|c|}
\hline Country & $\begin{array}{l}\text { Year } \\
\text { created }\end{array}$ & Coverage limits & Yearly premium & Funding & Administration \\
\hline Equatorial Guinea & 1999 & $\begin{array}{l}\text { ECU } 3,557 \text { (approx } 3 \text { x GNI per capita); } \\
\text { excludes interbank deposits. }\end{array}$ & $\begin{array}{l}\text { Risk based: } 0.15 \text { percent } \\
\text { of deposits }+0.5 \text { percent } \\
\text { of nonperforming loans }\end{array}$ & $\begin{array}{l}\text { Permanently } \\
\text { funded }\end{array}$ & $\begin{array}{l}\text { Joint private } \\
\text { and public } \\
\text { agency }\end{array}$ \\
\hline Kenya & 1985 & $\begin{array}{l}\text { US } \$ 1,750 \text { (approx } 5 \text { x GNI per capita); } \\
\text { excludes interbank deposits }\end{array}$ & $\begin{array}{l}0.15 \text { percent of average } \\
\text { quarterly deposits }\end{array}$ & $\begin{array}{l}\text { Permanently } \\
\text { funded }\end{array}$ & Public agency \\
\hline Philippines & 1963 & $\begin{array}{l}\text { US } \$ 2,375 \text { (approx } 3 \text { x GNI per capita); } \\
\text { excludes interbank deposits }\end{array}$ & $\begin{array}{l}0.2 \text { percent of average } \\
\text { quarterly deposits }\end{array}$ & $\begin{array}{l}\text { Permanently } \\
\text { funded }\end{array}$ & Public agency \\
\hline Tanzania & 1994 & $\begin{array}{l}\text { US\$376 (approx } 2 \text { x GNI per capita); } \\
\text { excludes interbank deposits }\end{array}$ & $\begin{array}{l}0.1 \text { percent of average } \\
\text { quarterly deposits }\end{array}$ & $\begin{array}{l}\text { Permanently } \\
\text { funded }\end{array}$ & Public agency \\
\hline Uganda & 1994 & $\begin{array}{l}\text { US } \$ 2,310 \text { (approx } 8 \text { x GNI per capita); } \\
\text { excludes interbank deposits }\end{array}$ & $\begin{array}{l}0.2 \text { percent of average } \\
\text { quarterly deposits }\end{array}$ & $\begin{array}{l}\text { Permanently } \\
\text { funded }\end{array}$ & Public agency \\
\hline
\end{tabular}

GNI Gross national income.

Source: Demirguc-Kunt and Kane (2001).

\section{RELATED NONFINANCIAL REGULATORY ISSUES}

68. Various components of the regulatory framework are closely interrelated and may be interdependent. For instance, the existence of a special law on microfinance or of a more general law on banking and finance that recognizes microfinance as a legitimate activity when carried out by authorized institutions is not a sufficient condition for the development of institutions providing microfinance services. On the part of MFIs, substantial investment may be required to bring their systems up to the standard required for formal reporting requirements. On the part of supervisory authorities, they may have to adapt regulations governing interest rates, collateral, and portfolio quality to the methodologies of microfinance for commercial financial institutions to become actively involved in microfinance.

69. Judicial procedures on ownership, security interest, and collateral issues. Much remains to be done in the three countries on reforming laws and judicial processes in relation to property rights, collateral law, and security interest, not only for microfinance transactions, but also for the financial sector as a whole. Tanzania has taken significant steps to modernize and improve its legal system and judicial processes for resolving commercial disputes, as illustrated in box 2. Tanzania's approach to unclogging the heavy load of cases brought before the High Court is an innovative approach that can provide illustrative lessons for other countries in the region and elsewhere.

70. Tax and fiscal policy issues. Tax laws on admissible expenses, for instance, provisioning for possible loan losses, need to be synchronized with the requirements for prudentially acceptable operational procedures of financial institutions. The Bank of Tanzania's requirements and procedures for asset

15 Deposit insurance coverage in the countries cited is clearly narrow in scope (it excludes interbank deposits) and low in coverage limits per account. In the case of the Philippines and Tanzania, membership in the deposit insurance system is compulsory for banks and institutions that are authorized and licensed to accept deposits, and their premiums are assessed and collected quarterly. Financial institutions that are neither regulated nor supervised by the central banking/supervis ory authority, for example, NGO MFIs and CFIs, or that may be registered with the banking authority and may be authorized to mobilize wholesale institutional deposit funds through large-value certificates of time deposit or money market instruments but are not authorized to accept retail deposits from the public, are not part of the formal deposit insurance system. The financial cooperative sectors in the countries studied count on a significantly large base of members, whose savings deposits in their respective CFIs may therefore be at risk of loss because of a variety of factors, including fraud. 
classification and provisioning for delinquent loans follow international standards; however, the current tax regime does not permit banks to record provisions for possible loan losses as allowable expenses in their statement of income and expenses for tax purposes, thereby discouraging compliance.

71. Labor laws and regulations. Labor laws on institutional employment continue to present obstacles for financial institutions in general, including MFIs, in their attempts to become more efficient. For instance, in Tanzania firing employees, even for just cause such as fraud, is virtually impossible. Such laws are clearly a substantial deterrent to progressive employment and personnel development programs and practices and need to be reviewed and reformed.

Box 2. Facilitating Dispute Resolution through the Commercial Court, Tanzania

Tanzania recently established a separate Commercial Court to ensure the efficient processing and timely resolution of commercial disputes. By avoiding procedural bottlenecks, the court can settle disputes expeditiously and efficiently for the benefit of all parties involved. There is no fixed definition of a commercial case. Broadly, it covers the liabilities of a business person, commercial organization, or individual arising out of commercial or business activities. It also involves the structuring or payment of commercial debt by or to a business person, commercial organization, or individual. The value of cases handled by the court ranges from T Sh 10 million to T Sh 300 million (US $\$ 12,500$ to US $\$ 37,500$ ).

The court's mandate includes streamlining procedures to facilitate the quick res olution of commercial disputes. Alternative dispute resolution remains available to the Commercial Court, which promotes mediation and other forms of settlement to avoid trials. The government introduced these options because of congestion and excessive delays in the disposal of court cases.

The 43 staff members of the Commercial Court include three judges, one registrar, and a number of deputy registrars. While it enjoys a degree of autonomy in financing and staffing, the court is constitutionally an integral part of the High Court of Tanzania and its staff members are employees of the judicial system. Both parties to a case are required to pay court fees when documents are filed. The fee, currently set at 3 percent of the claim amount, is significantly higher than that payable in the High Court.

Bankers and members of the business community have expressed appreciation of the Commercial Court and are satisfied with its performance, as most cases were resolved within three months. In 2000 the court resolved 104 cases. In 2001, 185 cases were filed and the court had already decided 110 cases during the first seven months of the year.

Source: World Bank 2001.

\section{MAIN FINDINGS}

72. The worldwide success that MFIs and microfinance programs have achieved in making financial services accessible to the poor and microenterprises has spawned initiatives to expand them. The regulatory policy responses of governments have ranged from deliberate efforts to promote microfinance development by establishing special regulatory niches to control of heretofore unregulated MFI activities. An intermediate approach has been to integrate commercial microfinance into the formal financial sector by adjusting existing regulatory structures to accommodate and legitimize the provision of microfinance services by various types of institutions.

73. A central issue is whether licensing promotes or discourages the integration of microfinance methodologies into the financial system. Regulations that prevent specialized, commercially-oriented MFIs from entering the market or commercial banks from going down-market can be considered unduly restrictive. Regulations that permit the licensing of sufficiently qualified MFIs and are adapted to the nature of microfinance portfolios can facilitate financial system development that reaches poorer clients. Regulations and government credit programs that prevent MFIs from evolving as self-sustainable financial institutions tend to marginalize microfinance. Based on the countries studied and on other experiences, the financial sector regulatory framework generally compartmentalizes MFIs into several categories, accommodating some forms as licensed financial institutions (with varying degrees of restriction on entry), while allowing others to operate outside the formal regulatory framework. In a few cases the responsibility for regulation is shifted to agencies other than a central banking authority. 


\section{OPENING THE FORMAL REGULATORY FRAMEWORK TO PROMOTE GROWTH OF MICROFINANCE}

74. The approaches to microfinance regulation in the countries studied could be characterized as strategic policy choices to develop sustainable microfinance. In Benin and other UMOA countries, the law sought to only promote credit unions despite the existence of a large number of microfinance NGOs, which continue to provide microfinance services by virtue of the legalized accommodations in an otherwise highly restrictive legal and regulatory framework. However, the convention-cadre or simple permit process which allows non-credit union MFIs to operate may not serve as a suitable basis for further rapid expansion of organized, sustainable microfinance. The convention-cadre with the Ministry of Finance does not provide clear and standard conditions or a basis on which non-credit union entities can engage in the business of providing microfinance services. In Ghana the authorities created new regulatory categories for licensed institutions to permit the entry of new types of financial intermediaries - RCBs under the existing law and S\&Ls and other MFIs under the new NBFI Law - even though this was not motivated by a microfinance strategy as such. In Tanzania the existing banking laws and regulatory framework permitted the entry of licensed banking institutions serving specialized and limited market niches, but this did not result in a large-scale emergence of MFIs using these regulatory categories. The new Law on Microfinance establishes a framework for institutions specializing in microfinance, that is, licensed microfinance companies and CFIs, although a risk exists that the regulations may make Tanzania's overall framework for microfinance more restrictive.

75. The perspectives that have been extracted from the experiences of Benin, Ghana, and Tanzania can be enriched by reviewing the experiences of other countries. South Africa's approach to consumer credit microlending through exemption from interest rate ceilings under the Usury Act affords little access to external funds for authorized providers of microloans that are not licensed banks or CFIs that are exempt from the Banking Act. As a result the financial sector is segmented and compartmentalized, and establishing a legal mechanism to circumvent the Usury Law is a major incentive in the complex regulatory framework for microfinance. Uganda's microfinance industry includes a commercial bank, a licensed "Tier 2" nonbank microfinance institution, about 90 national and international NGOs operating specialized MFIs, at least 700 smaller multisectoral NGOs and community-based organizations engaged in microf inance, and several hundred cooperatives and member-based savings and credit organizations, as well as informal savings and credit groups and moneylenders. A number of donor and government programs are also active in the sector, including programs for capacity building, for advising the Bank of Uganda, and for wholesaling funds to small MFIs.

76. The push in Uganda in the late 1990s for a special regulatory niche for microfinance institutions came in part from the leading NGO MFIs, of which at least four specialized only in microfinance, and which wanted to be able to take savings deposits legally as a basis for expansion. At the same time the Bank of Uganda became increasingly concerned about the risks to poor people's savings in MFIs and village banks that were being promoted under donor programs, especially in the light of commercial bank failures. Despite potential conflicts between the objectives of the practitioners and of the Central Bank's regulators, a consultative process over about four years yielded the 2003 Microfinance Deposit-taking Institutions Act, which establishes a new "Tier 3" for MFIs that wish to take and intermediate deposits from the public to become licensed with a substantially lower minimum capital requirement (US\$0.4 million) than for commercial banks (US\$2.3 million). Other MFIs, including credit NGOs and small, member-based savings and credit associations, are left outside the Bank of Uganda's supervisory responsibilities, although Parliament required that legislation for regulation of "Tier IV" MFIs be prepared as a condition of passing the MDI Act.

77. Ethiopia's 1996 Law on Licensing and Supervision of Micro-Financing Institutions shifted the basis of microfinance from humanitarian-oriented projects to commercially-oriented financial intermediation. As a result Ethiopia now has 21 licensed MFIs, with strong rural penetration and high operational efficiency, some of which have reached a significant scale (two have more than 200,000 clients). Nevertheless, the system has some weaknesses in terms of restrictiveness, supervision capacity, compliance with regulatory norms, governance, and lack of flexibility. Only wholly Ethiopian-owned corporations can be licensed, prohibiting NGOs from engaging in microfinance even with their own funds. The only other legal form of 
microfinance is savings and credit cooperatives, which the Central Bank does not regulate. Supervision capacity has lagged far behind, and MFIs have not complied with audit requirements. MFIs are generally sponsored indirectly either by regional governments or NGOs, and a disconnect is often apparent between board members and sources of capital. The law restricts MFIs to group lending methodology and to loans below about US\$600. Even though many of Ethiopia's MFIs have reached high levels of operational efficiency, these restrictions along with pressures to keep interest rates low hinder their achievement of financial self-sufficiency.

78. Peru's experience provides some useful lessons on the benefits of a regulatory framework that facilitates integration of commercial MFIs into the financial system, in contrast to compartmentalizing microfinance from the overall financial system. Amendments to the Banking Law in 1995 allowed for the establishment of entidades de desarrollo para la pequeña y micro empresa (development finance institutions for small and micro-enterprises or EDPYMEs) with minimum capitalization of about US\$265,000, as well as a simplified system for loan analysis, classification, and provisioning. The implementing regula tions issued by the Superintendency for Banks and Insurance Companies stipulate a capital base of US\$1 million and the attainment and maintenance of prescribed risk ratings for two years before the superintendency can authorize an EDPYME to accept savings deposits (Jannson and Wenner 1997). EDPYMEs can access commercial bank credit, equity markets, and special rediscount facilities from the Peruvian Development Bank. To access capital markets, EDPYMEs must register with the Securities Commission and submit year-end audited accounts. The EDPYME legal structure allows for a period of transition to fully regulated status.

\section{SEQUENCING POLICY REFORMS AND SPECIAL LEGISLATION}

79. A core aspect of the sequencing of policy reforms is whether or not introducing a regulatory framework that specifically addresses microfinance is an effective way to attract the entry of good, knowledgeable institutional providers of microfinance services where few or none may have existed. Do the three countries' experiences in the evolution and development of their respective microfinance sectors support this proposition? If the answer is no, or if the available data are inconclusive, then identifying other significant factors or influences would be useful. For instance, Uganda's experience shows that a variety of viable and sustainable MFIs can emerge and develop without a microfinance-specific regulatory framework in place, and that legislation to amend the regulatory framework can take place once it becomes essential to accommodate commercially-oriented microfinance.

80. Benin. The emergence of credit unions and of NGO and other non-credit union MFIs in Benin preceded the establishment of microfinance-specific legislation and regulatory frameworks, which then laid the ground rules for them to become legitimate financial intermediaries. However, the lack of clarity regarding the status of entities other than credit unions permitted through the convention cadre has created uncertainty as to whether they will eventually be permanently accommodated within the PARMEC Law.

81. Ghana used the existing Banking Law and the new NBFI Law to open up new forms of licensed financial intermediaries that could provide rural and microfinancial services. Nevertheless, a microfinance-specific regulatory framework did not exist until changes in the business rules for NBFIs addressed the issues of specific intermediation and financing activities by different categories of institutions. The S\&L category in the overall financial regulation framework permitted the entry of private investment to serve a particular market niche on a smaller scale than that required for commercial banks and the transformation of NGOs. While Ghana succeeded in applying commercial principles to microfinance and innovating in relation to the financial linkages between commercial and informal entities, the number and weakness of the resulting institutions overwhelmed the supervisory authorities' limited capacity to apply the regulatory guidelines. These difficulties led to a subsequent increase in restrictiveness via a higher minimum capitalization requirement to restrain new entry. Thus one lesson is that if countries reform their regulations to make them more accommodating, they must strengthen their supervisory capacity commensurate with the likely extent of entry. 
82. Tanzania's financial sector regulatory framework includes licensing categories for limited-service regional and community banks, but the low capitalization levels for entry do not appear to have encouraged the larger and more successful NGO MFIs to seek out these licensed categories as opportunities for transformation. With the recent establishment of a microfinance-specific legal and regulatory framework, Tanzania will provide a good case study of whether or not installing such a framework is an effective way to attract the entry of desirable international investors into the microfinance industry.

\section{IMPACT OF REGULATORY FRAMEWORK ON MICROFINANCE DEVELOPMENT}

83. Benin generally treats microfinance as separate from the banking and financial system, yet requires formal status for all entities whether they mobilize savings or not. This has not proven effective in integrating microfinance into the commercial financial system or in rendering effective supervision where it is most needed. The BCEAO Law governs the business operations of commercial banks and NBFIs, which are supervised by the Regional Banking Commission, with no accommodation made for them to engage in microfinance activities. The PARMEC Law, which enables entities other than licensed commercial banks and NBFIs to provide microfinance services, recognizes only the credit union organizational format for entities authorized and licensed to provide savings and credit services to microfinance clients, but supervision rests with the Ministry of Finance, which lacks the capacity and skills to do so effectively. While non-credit union entities may legitimately provide savings and credit services through an interim, time-bound authorization from the Ministry of Finance, clarity is lacking about their long-term status and the ministry's discretionary powers. This situation is not conducive to serious efforts to build up the MFIs' outreach and their financial and institutional capacity or to improve the technical supervision capacity of the ministry's Microfinance Unit (Ouattara 2003).

84. Ghana's experience underscores the importance of developing an inclusive regulatory framework that accommodates different formats of formal (as well as informal) rural and microfinance institutions, including moving to make CFIs part of the prudentially regulated financial sector. Perhaps in part because of this variety of legal formats, NGOs have failed to emerge as a significant organizational format for microfinance providers, although they have pioneered new methodologies in collaboration with other financial institutions. Financially viable microfinance NGOs now face a relatively high barrier to transformation because of the recent substantial increases in the minimum capitalization requirement for becoming a lic ensed NBFI under the S\&L category, which was perhaps intended to restrict the burden on Ghana's limited supervision capacity.

85. Tanzania's recently passed legal and regulatory framework is being re-oriented to achieve a sought-after commercialization of microfinance and the development of institutional providers of microfinance services into sustainable, licensed MFIs, depending on the implementation regulations. Even as the minimum capitalization requirement for commercial banks has been raised from US\$1.00 million to US\$5.0 million, the banking authorities are considering a much lower minimum capitalization requirement for licensed microfinance companies or CFIs, at between US\$500,000 to US\$800,000. Even though this is less than the new minimum capitalization requirement for S\&Ls in Ghana, the regulations for implementing the new law introduce complex and stringent financial accounting and reporting requirements that may be beyond the technical capacity and resource endowments of Tanzanian microfinance NGOs and CFIs. Thus, while the structure of the regulatory framework is accommodating on the surface, whether it strikes the right balance between facilitating and restricting new entry remains to be seen.

\section{REGULATING ACTIVITIES OR INSTITUTIONS}

86. In creating an overall regulatory framework for the financial sector that also accommodates the provision of financial services to the economically active poor and to low-income households, the objectives of new or additional regulation must be clear. What exactly will a supervisory authority regulate? The two possible objects of regulation are the financial intermediation activity or the institution carrying out the 
activity, although these are not mutually exclusive choices. Regulations will identify and define the specific financial activities covered, but the same regulations will generally also focus on and differentiate among the institutions engaged in the regulated activities.

87. Thus regulations must include a readily understood, unambiguous, legal definition of microfinance services. Among other considerations, having such a definition of the microfinance product and the microfinancing activity helps to forestall and minimize the use of regulatory arbitrage by investors whose interests may lie in securing entry for their financial institutions as licensed entities with the least possible amount of investment, but without becoming substantively involved in microfinance.

88. The Bank of Ghana's rules and regulations for NBFIs and Tanzania's new Law on Microfinance provide clear definitions of microfinancial services and products. Other useful examples include Uganda's new Microfinance Law; the Philippine Central Bank's recent circulars on microfinance loans and on institutions engaged in microfinance; Peru's regulations establishing the category of EDPYMEs for micro-enterprise and finance for small and medium enterprises; and Bolivia's banking regulation amendments creating the private financial fund status for micro, small, and medium enterprise finance.

\section{DISTINGUISHING BETWEEN PRUDENTIAL SUPERVISION AND REGULATORY OVERSIGHT}

89. The objective of prudential supervision is to ensure the financial soundness of institutions that have been authorized to carry out financial activities subject to certain restrictions. The licensing authority effectively vouches for the soundness of licensed financial institutions and the safety of public funds that they accept and intermediate. Prudential supervision includes off-site monitoring, on-site examination of documents, internal and external reports, and other actions to verify compliance with prudential standards and guidelines. The authority to supervise includes the power to impose sanctions for noncompliance and, at the extreme, to take over, close, and liquidate institutions in case of flagrant uncorrected violations.

90. Regulatory oversight is concerned with ensuring that business operations are conducted in accordance with accepted standards of fair business practices. Such oversight is sometimes called nonprudential regulation, because of the regulatory body's significantly diminished control over regulated financial institutions' operations and activities. Oversight is generally carried out through periodic submission and monitoring of operating and financial reports, including externally audited annual financial statements.

91. While licensed banks are subject to prudential supervision as deposit-taking institutions, finance companies that do not take deposits may be subject only to regulatory oversight, although the general public may not be fully aware of the distinction. The central banking authority does not vouch for the soundness of the latter type of financial institution, thus investors in the commercial paper or securities issues of regulated finance companies are at full risk in the event of business failure by such an institution. In the three countries studied, as well as in other countries, CFIs that are not under the jurisdiction of and subject to licensing by the central banking authority are not part of the prudential supervision structure. Neither are nonbank NGO MFIs, even though they may be required to go through a registration process with a regulatory authority or agency. The exception is Benin, where credit unions, non-credit union MFIs, and NBFIs are subject to licensing in one form or another.

\section{INSTITUTIONAL AND TEC HNICAL CAPACITY CONSIDERATIONS}

92. Capacity building considerations fall into three main areas: (a) the technical capacity of directors, managers, and staff of MFIs, especially of CFIs; (b) the technical capacity of staff in regulatory agencies to carry out the required regulatory oversight and, when necessary, prudential supervision of regulated and licensed MFIs; and (c) the financial and technical resources for creating new regulatory and supervisory policies, processes, and agencies appropriate for microfinance. An unbalanced approach results in inadequate attention to supervisory capacity and costs in the design of the regulatory framework. The experience of MFIs in other countries demonstrates that mobilizing savings and managing them safely and profitably entails a more complex set of skills, systems and resources than accessing and intermediating wholesale commercial funds. Using the regulatory framework to push microfinance development is likely 
to result in overlooking other less costly and less technically demanding approaches to commercializing microfinance, e.g., regulations that enable MFIs to access commercial funds from licensed banks and forge strategic alliances with the formal financial sector.

93. The benefits from regulating microfinance may be limited when commercial banking standards are applied to MFIs without adequate consideration of microfinance methodologies. For supervision to be effective, the data requirements and the indicators used must be adapted to the operations of MFIs, and they in turn must adapt their information systems to central bank reporting requirements. Given the short-term nature of MFI loan portfolios, more rigorous standards in certain areas, such as portfolio quality and provisioning, together with more frequent monitoring, may be warranted. This raises a further issue that has received scant attention: measuring and paying for the costs of supervision. The costs of supervising MFIs are likely to be greater than those for commercial banks, especially when the more numerous and small MFIs outnumber the banks. Moreover, supervision fees are usually set as a percentage of the value of assets examined, and MFIs' asset bases are much smaller than those of banks.

\section{LOCATING THE AUTHORITY FOR REGULATION}

94. The different approaches to prudential regulation of MFIs tried in a number of countries fall into three main categories: (a) regulation and supervision by the banking authority; (b) regulation and supervision by a specialized agency separate from the banking authority as an auxiliary or under a delegation arrangement; and (c) regulation and supervision through a self-regulatory body, usually the umbrella organization for specific categories of MFIs. Insofar as Benin, Ghana, and Tanzania are concerned, approaches toward prudential regulation of institutions involved in microfinance activities consist of regulation and supervision by the banking authority in combination with one or more of the other approaches.

95. An important issue is the extent to which regulatory authority should be centralized, delegated, or decentralized. Like many other countries in Africa, the microfinance regulatory frameworks of Benin, Ghana and Tanzania have come into being under circumstances of fragmented authority. A central bank authority is responsible for prudential supervision of licensed banks and financial institutions, a cooperatives authority is responsible for member-based SACCOs (usually focused on registration and cooperative principles rather than financial performance), and NGO MFIs are registered with nonfinancial government agencies. In deciding how best to implement regulatory responsibilities, two distinctions are important: regulatory policy should have a single locus, while application of regulatory functions can be delegated to different regulatory units with specialized responsibilities; and the criteria and authorities for prudential supervision should differ from those for non-prudential regulatory oversight.

- The BCEAO and the Regional Banking Commission have jurisdiction over the regulation and supervision of commercial banks and NBFIs in Benin. Under the PARMEC Law, the Ministry of Finance is responsible for regulating and supervising credit unions and non-credit union MFIs. However, the delegation of supervisory functions by the regional central bank of UMOA to Ministries of Finance has proven ineffective in the prudential supervision of microfinance activities and institutions.

- The Bank of Ghana has jurisdiction over banks and NBFIs, and the draft Credit Union Law envisages supervision over CFIs by a new Credit Union Supervisory Board, separate from both the Bank of Ghana and the Department of Cooperatives. Currently the CUA and the Department of Cooperatives jointly exercise quasi supervision through annual examinations and audits. NGO MFIs are outside the Bank of Ghana's jurisdiction. Insofar as RCBs are concerned, the plan is to delegate supervision to the Rural Bank Apex Bank (specially licensed as a second-tier financial institution serving the RCBs).

- The Bank of Tanzania has jurisdiction over banks, NBFIs, and the new category of licensed microfinance companies and CFIs provided for by the new Law on Microfinance. The Ministry of Cooperatives and Marketing regulates SACCOs, although it appears to share this function somewhat with local governments under the provisions of the Decentralization Law, and the Savings and Credit 
Cooperative Union League of Tanzania, an upper-tier federation of CFIs, provides some selfregulatory oversight.

\section{INTEGRATING COOPERATIVE FINANCIAL INSTITUTIONS INTO THE MICROFINANCE SECTOR}

96. Financial cooperatives offer important potential for decentralizing access to financial services, particularly in rural areas that banks and commercial MFIs may find too costly to reach. But it has proven difficult both to promote their growth as sustainable financial intermediaries and to integrate them into formal financial regulatory systems. In the three countries CFIs constitute an important and comparatively large segment of the microfinance industry in terms of the number of institutions and their membership base. Governments of most countries, as well as the donor community, need to focus more attention on measures to make the microfinance industry an integral part of the overall financial sector, including the CFI segment, which is still generally being treated as part of the cooperative sector rather than of the financial system. CFIs require special attention during the structuring of specialized microfinance regulatory frameworks. Technical capacity building is important not only for paid staff, but also for CFI directors and committee members, who often consist of member volunteers.

97. While Benin's microfinance law prioritizes financial cooperatives, the supervisory burden has proven overwhelming, aggravated by responsibilities for also supervising non-deposit-taking MFIs. Financial policy-makers in Ghana and Tanzania have begun to recognize the need to incorporate financial cooperatives into the regulatory framework, athough they are effectively excluded in the practical application of financial regulations. Ghana's proposed approach of recognizing dual responsibilities of central bank and cooperatives authorities for CUs, with some delegation of front-line supervision to the apex body, appears promising and bears watching. Related to institutional strengthening and the build up of technical capacity, Tanzania needs to make the regulatory oversight or prudential regulation structure over CFIs consistent with the intent of the national microfinance policy and a proposed microfinance law. The regulatory jurisdiction is overlapping, and gaps generated by the Decentralization Law need to be closed.

\section{KEY LESSONS LEARNED}

\section{ORGANIZATIONAL FORMATS FOR MICROFINANCE}

98. The experience of many countries suggests that implementing a policy to harness microfinance methodologies to help reduce poverty by providing low-income households and microenterprises with greater access to financial services depends on having in place a diverse range of MFIs targeting different niches, and that introducing different approaches and products is important. The result can be facilitated by a flexible policy approach that opens the formal regulatory framework to the forms that microfinance can take, especially in the early stages of development (as in Ghana and Tanzania). A country that has a financial sector regulatory framework that unduly restricts or prescribes the provision of microfinancial services - whether through usury law ceilings on interest rates, outright prohibition on financial services by unlicensed entities (as in Benin, Ethiopia, and South Africa), or steep barriers to obtaining licensed status-is less likely to develop an effective microfinance industry that is well integrated with the financial system. Although restrictive policies that essentially marginalize microfinance outside the regulated financial system will not necessarily prevent the emergence of nonfinancial and semiformal microfinance entities providing financial services, they may create uncertainty regarding the status of MFIs and retard their evolution into providers of commercial services.

\section{TIERED STRUCTURES AND FINANCIAL DEEPENING}

99. The explicit recognition of different tiers of institutions in the financial structure, both regulated and unregulated, facilitates financial deepening and outreach to otherwise underserved groups, especially rural areas and the poor. A tiered financial systems approach recognizes the important roles 
of both regulated and unregulated institutions in the microfinance system, including grassroots savings and credit groups, microfinance NGOs, universal commercial banks, finance companies, cooperative banks, other specialized and regulated MFIs, insurance companies, and wholesale financing institutions. Worldwide, the outreach of microfinance tends to be greatest where the legal and regulatory system incorporates financially sustainable microfinance through licensed financial intermediaries, including specialized MFIs that can mobilize commercial sources of funds, without excluding credit-only MFIs using other people's money or small member-based CFIs. Nevertheless, policies, regulations, and legal structures need to balance promotion of the microfinance industry with, first, the obligation to protect savers and investors, and second, the costs of supervision to both the regulatory authorities and the licensed MFIs.

100. A licensed tier with appropriate regulations that is accessible to high-performing MFIs can encourage capacity building and innovation aime $d$ at reaching both self-sufficiency and outreach. However, integrating microfinance into the financial sector does not mean that all microfinance institutions ought to be regulated, but rather is intended to encourage strong regulated and unregulated institutions of all types to provide services on a sustainable basis under shared performance standards and to encourage the regulatory authorities to develop appropriate prudential regulations and staff capacity. One or more tiers of deposit-taking institutions could be encouraged to emerge by setting lower minimum capitalization requirements while (a) limiting activities under the institutional charter (for example, to micro-enterprise and small and medium business lending and to non-demand deposits); (b) placing caps on loan sizes or overall assets; and/or (c) tightening prudential standards in such areas as capital adequacy ratios, risk weighting of assets, liquidity, and loan loss provisioning.

- This approach can open a window for alternative specialized institutions that benefit from different cost and regulatory structures. The developing countries outside Africa whose financial sectors are characterized by tiering include Indonesia and the Philippines in Asia and Bolivia and Peru in Latin America, where the financial system regulatory framework permits a wide range of institutional providers of microfinance services in a multitiered structure, and the microfinance sector generally appears to be much larger, to consist of more diverse institutions, and to have better prospects for selfsustainability.

- Ghana has a wide range of MFIs, both explicitly licensed (rural banks, S\&Ls, credit unions) and tolerated (susu collectors, NGOs, and self-help groups), but it has not achieved great success in reaching scale and self-sustainability. Benin's restrictive approach, which focuses on microfinance via credit unions as the only legally authorized format, appears to be giving way to tacit acceptance of a more tiered structure. South Africa's regulatory adjustments to allow and regulate microlending as an exemption from the Usury Law have resulted in explosive growth, not only in the volume of microcredit loans, but also in the variety of institutions seeking the exemption and engaging in the business of providing consumer microcredit. A possible lesson may be that under certain favorable conditions, including a strong formal commercial financial sector and the existence of enforceable security (in this case, via wage employment), regulating a profitable product can facilitate rapid commercialization.

\section{THE REGULATORY FRAMEW ORK AND MICROFINANCE DEVELOPMENT}

101. The experience in the three countries does not support the proposition that establishing new regulatory categories will necessarily promote commercialization of microfinance or the creation of financially sustainable MFIs where few or none exist. Experiences in other countries such as Uganda and Kenya show that a variety of viable and sustainable MFIs can emerge and develop without a microfinance-specific regulatory framework, while microfinance continues to flourish in Benin despite a restrictive legal and regulatory framework. When there is a critical mass of viable microfinance providers, new legislation to amend the regulatory framework is likely to be more productive in facilitating the transformation of high-performing non-bank MFIs to licensed status in a specially adapted niche - which is the approach that Uganda and Kenya are now taking. In Tanzania, the rationale for the new Law on 
Microfinance Companies is to attract international microfinance institutions and investors into Tanzania's microfinance market, although it is premature to draw conclusions about its success. By enabling successful NGO MFIs to evolve to the next stage, Uganda's new law appears to be triggering an inflow of investment and capacity-building assistance to help existing large MFIs to make the transformation, and urban competition is already driving some to seek more rural outlets in anticipation of becoming licensed to take savings. While Ghana's NBFI Law and low minimum capitalization requirement for S\&Ls facilitated entry and transformation, the rate of entry and weak performance exceeded the capacity of supervisory authorities.

102. The capacities of authorities to implement their regulatory obligations and of MFIs to comply are a critical constraint on the effectiveness of new legislation in promoting and regulating microfinance. Setting up new licensing categories for rural banks and savings and loan companies in Ghana did stimulate entry of new types of MFIs that helped broaden and deepen access to financial services. Nevertheless, neither the institutions nor the regulatory authorities had adequate technical capacity to ensure compliance with regulatory standards, leading subsequently to more demanding requirements as a barrier to new entry. New legislation in Benin and Tanzania brought existing non-bank MFIs under licensing and supervisory requirements, but the goal of forcing improvements in their financial performance is not likely to be realized, because the coverage of institutions greatly exceeds the capabilities of the designated supervisory authorities and the non-bank MFIs targeted for regulation are organizationally and financially weak.

103. The development of a new regulatory framework for microfinance should be accompanied by complementary modifications of other business laws and regulations. This is true especially in the areas of taxation, contract enforcement, collateral registration and enforcement, securities regulations and consumer protection. These laws and administrative rules also need to be adapted to microfinance methodologies, where loan transactions and the legal status of borrowers differ markedly from those in conventional commercial banking and finance.

\section{INSTITUTIONAL AND TECHNICAL CAPACITY FOR PRUDENTIAL SUPERVISION}

104. The creation of microfinance legal and regulatory structures should be accompanied by substantial up-front investment in raising the awareness of policymakers, consulting with stakeholders, improving syste ms and staff capabilities in MFIs to be regulated, and staffing up and training the supervisory authorities. As the microfinance sector develops in response to demand from underserved segments, the overall regulatory framework for the financial sector is likely to be subjected to pressures for adjustments and changes, as is the case in all three countries studied. Hasty passage of new laws or introduction of government programs without adequate consultation or awareness of good (and bad) practices risks putting in place systems with a short-term focus that may undermine longer-term development objectives. Opening up formal licensing to MFIs too rapidly may overwhelm the capacity of the supervisory authorities.

105. An unbalanced approach results in inadequate attention to supervisory capacity and costs in the design of the regulatory framework. The experience of MFIs in other countries demonstrates that mobilizing savings and managing them safely and profitably entails a more complex set of skills, systems and resources than accessing and intermediating wholesale commercial funds. Using the regulatory framework to push microfinance development is likely to result in overlooking other less costly and less technically demanding approaches to commercializing mic rofinance, e.g., regulations that enable MFIs to access commercial funds from licensed banks and forge strategic alliances with the formal financial sector.

106. Regulators and supervisors should deliberately distinguish between licensed deposit-taking MFIs whose financial soundness they verify through prudential supervision versus categories of MFIs that may be registered, but for which the government bears no responsibility. The absence of a formal deposit protection system generates a fiscal exposure and risk for the government that makes publicizing this distinction especially important. In particular, regulators and supervisors should exclude nondeposittaking, credit-only MFIs from their prudential supervisory activities to conserve scarce supervisory resources and because the public's savings are not at stake. In such cases donors, banks, and other funders 
can be expected to exercise adequate oversight. Small member-based savings and credit associations are normally excluded from direct prudential supervision by the regulatory authorities, although regulatory oversight by an independent body or industry association is desirable to gather data and report on performance in meeting established standards. Nonsupervised MFIs may even be required to periodically submit to a designated oversight agency certified reports and supporting schedules on financial results and business operations, according to a prescribed set of formats and standards, for example, a ceiling on permissible debt-equity ratios, liquidity of assets, portfolio quality, and provisioning guidelines.

\section{SEQUENCING OF POLICY IS STRATEGIC TO AN EFFECTIVE FRAMEWORK}

107. A national strategic planning process for microfinance policy can be useful in building consensus on the broad approach to developing microfinance as part of financial systems development, and perhaps occasionally in providing alternatives to politically motivated programs, but is neither necessary for development of the industry nor a guarantee against inconsistent approaches. In Tanzania and Uganda, the process of preparing a strategy helped build consensus and establish government withdrawal from direct intervention as a policy. A related issue is whether creating a specialized microfinance regulatory framework is effective in attracting the entry of good institutional providers of microfinance services. Permitting credit-only NGOs to operate legally is generally considered desirable to promote innovation and develop a microfinance industry serving relatively poor clients (although Benin's legal structure is somewhat restrictive with respect to NGO MFIs, and Ethiopia's prohibition was aimed in part at establishing a more businesslike approach to microfinance in place of its more donor-dependent, welfare-oriented approach). The conclusion is that the appropriate sequencing depends on each country's circumstances, and that it is most effective when the regulatory framework permits nonlicensed MFIs to evolve, establishes new licensed niches as the market develops, adjusts regulations in light of experience, and is accompanied by commensurate capacity building for the supervisory authorities. 
APPENDIX: Distinguishing FEATURES OF THE LEGAL F RAMEWORK FOR D IFFERENT TYPES OF MFIS

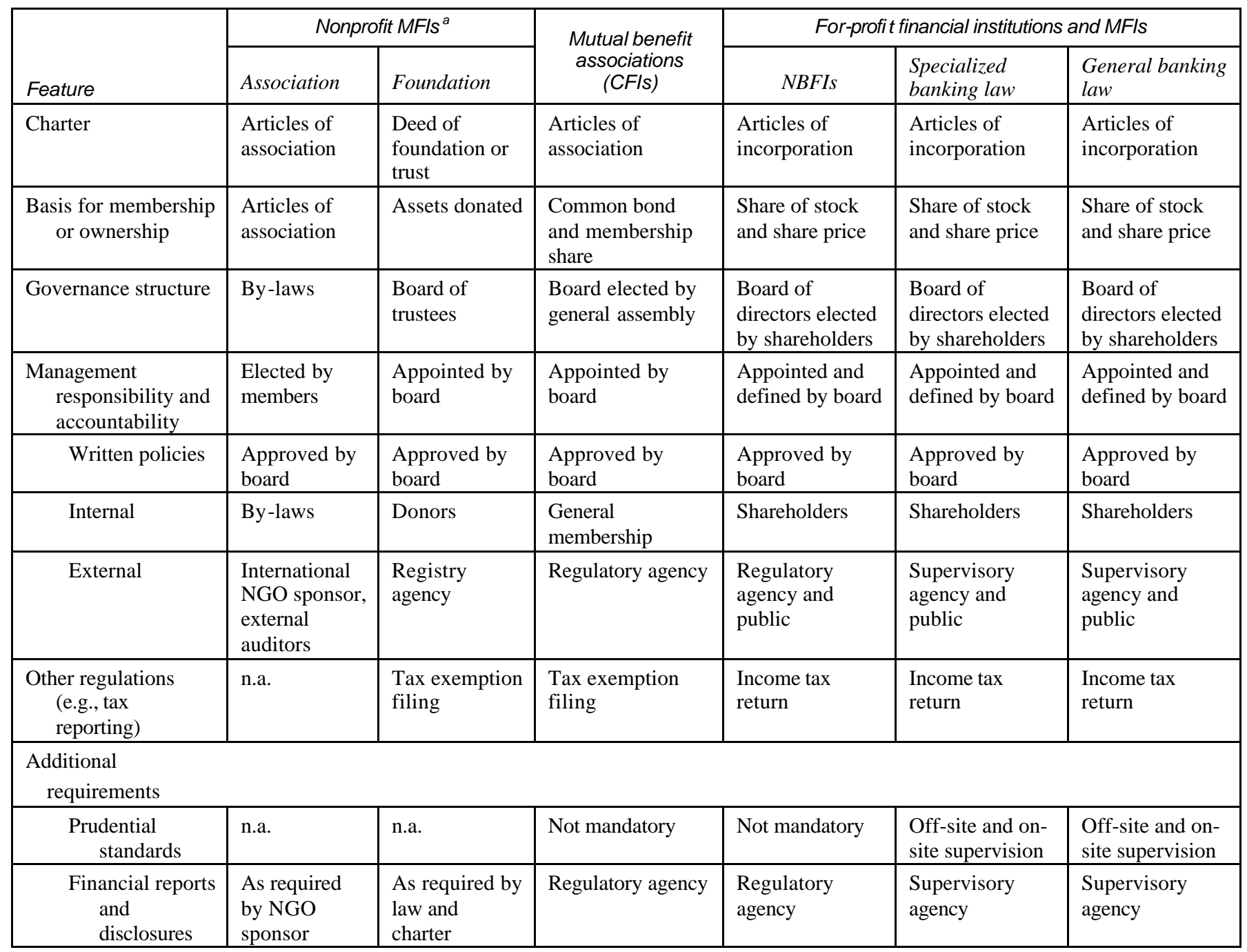

n.a. Not applicable.

Note: All categories except nonprofit associations would normally be required to have internal controls, external audits, records of meetings, and annual reports and would have specified regulatory standards and requirements for entry and exit as MFIs a. Many small NGOs are organized by like-minded individuals as unincorporated economic or social associations of individuals without seeking the approval of or registration with a government agency.

Source: Gallardo and Randhawa (2003); Ouattara (2003); Steel and Andah (2003). 


\section{REFERENCES AND B IBLIOGRAPHY}

Bank of Ghana, Nonbank Financial Institutions Department. 2000. Nonbank Financial Institutions Business Rules (As Applicable to Institutions in Credit Business). Accra: Government of Ghana.

Bank for International Settlements. 2001. Guidance for Developing Effective Deposit Insurance Systems. Final report of the Financial Stability Forum's Working Group on Deposit Insurance. Basel.

Bank of Tanzania. 2001. "Rural Savings and Credit Cooperative Soceties in Tanzania.” Draft report of a survey carried out by the International Co-operative Alliance Regional Office for East, Central, and Southern Africa for the Bank of Tanzania and several donor agencies. Dar es Salaam.

. 2000. Final Report: Microfinance Donor Survey Update. Prepared with technical support from the Canadian International Development Agency. Dar es Salaam: Government of the United Republic of Tanzania.

Christen, Robert P., and Richard Rosenberg. 2000. The Rush to Regulate: Legal Frameworks for Microfinance. Occasional Paper no. 4. Washington, D.C.: Consultative Group to Assist the Poor.

Demirguc-Kunt, Asli, and Edward J. Kane. 2001. "Deposit Insurance around the Globe: Where Does It Work?" Policy Research Working Paper, no. 2679. World Bank, Washington, D.C.

Gallardo, Joselito, and Bikki Randhawa. 2003. "Microfinance Regulation in Tanzania: Implications for Development and Performance of the Industry." Working Paper, no. 51 World Bank, Africa Region, Washington, D.C.

Ghana Microfinance Institutions Network. 2001. On-Lending to Savings Collectors in Ghana. Africa Region Studies in Rural and Micro Finance no. 12. Washington, D.C.: World Bank.

Jannson, Tor, and Mark Wenner. 1997. Financial Regulation and its Significance for Microfinance in Latin America and the Caribbean. Washington, D.C.: . Inter-American Development Bank, Sustainable Development Department, Microenterprise Unit.

Kowubaa, Ltd. 2000. "Rural Finance Study.” Report prepared for the Ministry of Finance and World Bank Nonbank Financial Institution Project. Accra.

Meagher, J. Patrick, and Betty Wilkinson. 2002. "Filling the Gap in South Africa's Small and Micro Credit Market: An Analysis of Major Policy, Legal, and Regulatory Issues.” Discussion Paper no. 02/01. Center for Institutional Reform and the Informal Sector at the University of Maryland, College Park, Maryland.

MIX. 2002. MicroBanking Bulletin, no. 8 2002. Washington, D.C.: Microfinance Information eXchange.

Ministry of Finance. 1999. "A Strategic Framework for Developing the Microfinance Sector in Ghana." Draft. Government of Ghana, Accra.

Ouattara, Korotoumou. 2003. "Microfinance Regulation in Benin: Implications of the PARMEC Law for Development and Performance of the Industry." Working Paper, no. 50. World Bank, Africa Region, Washington, D.C.

Owusu Ansah, Mark. 1999. Nsoatreman Rural Bank, Ghana: Case Study of a Microfinance Scheme. Africa Region Studies in Rural and Micro Finance no. 6. Washington, D.C.: World Bank.

Poyo, Jeffrey. 2000. "Regulation and Supervision of Credit Unions." In Glenn D. Westley and Brian Branch, eds., Safe Money: Building Effective Credit Unions in Latin America. Washington, D.C.: The Johns Hopkins University Press.

Quainoo, Aba Amissah. 1997. "A Strategy for Poverty Reduction through Micro-Finance: Experience, Capacities and Prospects." Draft study commissioned by the government of Ghana, the United Nations Development Programme, the African Development Bank, and the World Bank. Accra. 
Shiferaw, Bekele, and Wolday Amha. 2002. "Revisiting the Regulatory and Supervision Framework of the Micro-Finance Industry in Ethiopia." Report no. 13. Drylands Coordination Group, Norway.

Steel, William F., and David O. Andah. 2003. "Rural and Microfinance Regulation in Ghana: Implications for Development and Performance of the Industry." Working Paper, no. 49. World Bank, Africa Region, Washington, D.C.

Talley, Samuel, and Ignacio Mas. 1990. "Deposit Insurance in Developing Countries.” Policy Research Working Paper no. 548. World Bank, Washington, D.C.

Van Greuning, Hennie, Joselito Gallardo, and Bikki Randhawa. 1999. "A Framework for Regulating Microfinance Institutions.” Policy Research Working Paper no. 2061. World Bank, Washington, D.C.

von Stauffenberg, Damian. 2001. "How Microfinance Evolves: What Bolivia Can Teach Us." In Microenterprise Development Review. Washington, D.C.: Inter-American Development Bank.

Westley, Glenn D. 2001. Can Financial Market Policies Reduce Income Inequality? Technical Papers Series no. MSM-112. Washington, D.C.: Inter-American Development Bank.

Women's World Banking. 2002. "Policies, Regulations, and Systems That Promote Sustainable Financial Services to the Poor and Poorest." Paper prepared for the Microcredit Summit, November, New York.

World Bank. 2001. "Tanzania Financial Sector: The Way Forward.” Financial Sector Assessment Report. Washington, D.C.

. 2003. Briefing: Tanzania Financial Sector Fact Sheet; Tanzania at a Glance; Briefing: Benin Financial Sector fact Sheet; Benin at a Glance; Briefing: Ghana Financial Sector Fact Sheet; Ghana at a Glance. Washington, D.C.: World Bank. Available on: http://www-int.worldbank.org/intranet/jsp/sectors_view.jsp. 